\title{
Hydroxyurea Treatment for Sickle Cell Disease
}

\author{
Martin H. Steinberg, M.D. \\ Professor of Medicine and Pediatrics, Boston University School of Medicine, \\ 88 E. Newton St., Boston, MA 02118 \\ E-mail: msteinberg@medicine.bu.edu
}

Received March 1, 2002; Accepted April 5, 2002; Published June 25, 2002

High fetal hemoglobin (HbF) levels inhibit the polymerization of sickle hemoglobin (HbS) and reduce the complications of sickle cell disease. Pharmacologic agents that can reverse the switch from $\gamma$ - to $\beta$-chain synthesis $-\gamma$-globin chains characterize $\mathrm{HbF}$, and sickle $\beta$-globin chains are present in $\mathrm{HbS}$ - or selectively increase the proportion of adult erythroid precursors that maintain the ability to produce $\mathrm{HbF}$ are therapeutically useful. Hydroxyurea promotes HbF production by perturbing the maturation of erythroid precursors. This treatment increases the total hemoglobin concentration, reduces the vaso-occlusive complications of pain and acute chest syndrome, and attenuates mortality in adults. It is a promising beginning for pharmacologic therapy of sickle cell disease. Still, its effects are inconsistent, trials in infants and children are ongoing, and its ultimate value and peril - when started early in life are still unknown.

KEY WORDS: anemia, fetal hemoglobin, globin genes

DOMAINS: gene expression, molecular and gene therapy, hematology, clinical medicine, medical research, clinical trials, medical care

\section{INTRODUCTION}

The new millennium begins an era of remarkable promise for patients with sickle cell disease. Some have longer, more productive lives and their medical costs are reduced because of treatment with hydroxyurea. This review addresses the evolution of pharmacologic treatment for sickle cell disease focused on increasing the concentration of fetal hemoglobin ( $\mathrm{HbF})$ in erythrocytes.

More than 50 years ago, infants with sickle cell anemia were noted to have few symptoms during early life, an observation linked to their high $\mathrm{HbF}$ levels[1]. Compound heterozygotes for sickle cell trait and gene deletion hereditary persistence of $\mathrm{HbF}$, with more than $20 \% \mathrm{HbF}$ in all of their erythrocytes, were clinically normal despite having nearly $80 \%$ sickle hemoglobin 
$(\mathrm{HbS})[2,3] . \mathrm{HbF}$ and its $\gamma$-globin chains interfere with $\mathrm{HbS}$ polymerization; polymer concentrations sufficient to injure the red cell are a prerequisite for causing sickle cell disease. Inhibition of polymerization is localized to the acidic residues, $\gamma 80$ (Asp instead of $\beta 80$ Asn) and $\gamma 87$ (Gln instead of $\beta 87 \mathrm{Thr}$ ), however other residues could also be important[4]. In erythrocytes, $\mathrm{HbS}$ polymer is in equilibrium with $\mathrm{HbS}$ monomer whose concentration defines the solubility of $\mathrm{HbS}$. Unlike partially or fully deoxygenated $\mathrm{HbS}$, fully oxygenated $\mathrm{HbS}$ is excluded from the polymer phase. If $\mathrm{HbF}$ is mixed with $\mathrm{HbS}$, neither the $\mathrm{HbF}$ tetramer $\left(\alpha_{2} \gamma_{2}\right)$ nor the $\alpha_{2} \beta^{\mathrm{S}} \gamma$ hybrid tetramer enters the polymer. In contrast, the hybrid tetramer $\alpha_{2} \beta^{\mathrm{S}} \beta^{\mathrm{A}}$, has a 0.5 probability of entering the polymer.

Based on these observations, pharmacologic agents were sought that might reverse the neonatal switch from $\gamma$ - to $\beta$-globin chain synthesis[5]. Based on fundamental studies, cytosine hypomethylation was hypothesized to induce $\gamma$-globin gene expression, and the first "hemoglobin switching" agent, the nucleoside analog, 5-azacytidine, was postulated to work by causing hypomethylation of the $\gamma$-globin gene promoters. This drug increased $\mathrm{HbF}$ concentration in sickle cell anemia but was extremely toxic. Cytotoxic drugs incapable of directly causing gene hypomethylation also caused $\mathrm{HbF}$ to increase, perhaps indirectly, by perturbing the maturation of erythroid precursors[6,7]. In controlled clinical trials, one of these drugs, hydroxyurea, the principal topic of this review, increased HbF level and improved some symptoms of sickle cell anemia.

\section{HbF-INDUCING AGENTS}

Drugs may increase $\mathrm{HbF}$ by several different means; however, their mechanisms of action may overlap, and it is not always clear if a proposed mechanism is responsible for the observed effect.

Three different classes of drugs with the potential to increase HbF concentrations in patients with sickle cell disease and $\beta$ thalassemia have been the subjects of basic studies and limited clinical trials, but only one drug, hydroxyurea, is used in clinical practice. Before discussing this agent, the other two types of drugs will be briefly reviewed.

\section{Cytidine Analogs and HbF - An Effect of Gene Hypomethylation?}

Hypomethylation at $\mathrm{CpG}$ dinucleotides is usually associated with gene expression[8]. Usually, tissue-specific genes are hypomethylated only in the tissues where they are expressed so that, for example, in fetal erythroid tissue $\gamma$-globin genes are hypomethylated, while in adult erythroid cells they are methylated[9]. However, hypomethylation does not accompany all expressed genes, and whether or not gene hypomethylation is a primary cause or secondary effect of gene expression remains unclear[8,10]. Incorporation of certain cytidine analogs like 5-azacytidine into DNA inactivates the DNA methyltransferase responsible for gene methylation. These and other preclinical observations led to the use of 5-azacytidine to induce $\gamma$-globin gene expression in patients with sickle cell anemia[11,12,13].

5-Azacytidine increased $\mathrm{HbF}$ to between 30 and $81 \%$ of total hemoglobin in phlebotomized baboons[11]. In sickle cell anemia, 5 -azacytidine increased $\gamma$-globin mRNA in bone marrow cells, decreased methylation in the $\gamma$-globin gene promoter, increased F-reticulocytes, and increased total hemoglobin levels and $\mathrm{HbF}$ concentration[12,13,14]. Because of its toxicity, an analog of 5azacytidine, 5-aza-2'-deoxycytidine, which may have fewer adverse effects, has been studied. Nine patients who failed to respond to hydroxyurea with an increase in $\mathrm{HbF}$ synthesis were treated with this compound for 5 days a week over 2 weeks. After 4 weeks of treatment, all patients responded with a mean increase of $\mathrm{HbF}$ of nearly $7 \%$, with reversible mild neutropenia 
the sole adverse effect[15]. While studies are limited, 5-azacytidine may have a more profound effect on HbF levels than hydroxyurea, perhaps because of DNA hypomethylation and its cytotoxicity.

\section{Short Chain Fatty Acids and HbF — An Effect of Transcriptional Modulation?}

Short chain fatty acids like sodium butyrate induce reversible gene expression in cultured cells[16]. Sodium butyrate activated the embryonic $\rho$-globin gene in adult chicken cells treated with 5-azacytidine, suggesting that gene activation by butyrate may require an "active" chromatin structure[17]. Sodium butyrate is a histone deacetylase inhibitor, a class of agents that may change chromatin structure by causing histone hyperacetylation. When histone deacetylation is inhibited, the N-terminal lysine tails of histones $\mathrm{H} 3$ and $\mathrm{H} 4$ remain acetylated, favoring euchromatin that can be transcribed[18]. Butyrate may also affect $\gamma$-globin gene expression by binding transcriptionally active elements in the 5'-flanking region of the gene[19,20,21].

Sodium butyrate increased $\mathrm{HbF}$ in baboons and enhanced $\gamma$-globin gene expression in erythroid cells of patients with sickle cell anemia and $\beta$ thalassemia[22,23,24]. Initial butyrate trials in sickle cell anemia and $\beta$ thalassemia that continuously infused drug over a 2 - to 3-week interval gave inconsistent results, perhaps because of the antiproliferative effects of continuous drug dosing $[25,26,27,28]$. Butyrate restrains cell growth by inhibiting histone deacetylase, cyclin D1, and through cyclin-dependent kinase inhibitors, cyclin D and E activity[29]. When given only once or twice a month, arginine butyrate was associated with a mean increase in $\mathrm{HbF}$ from 7 to $21 \%$ in 11 of 15 patients with sickle cell anemia, and in some individuals, this level was maintained for 1 to 2 years[30,31]. Other short-chain fatty acids stimulated $\mathrm{HbF}$ production but have not been studied in clinical trials[27,31,32,33,34,35,36] Some of these agents do not inhibit histone deacetylase but stimulate cell growth and also induce HbF expression. This class of compounds has not been evaluated in phase- 3 studies. Presently, the use of any short chain fatty acid in sickle cell anemia remains experimental and should be restricted to clinical trials.

\section{Hydroxyurea and $\mathrm{HbF}$ - An Effect of Cytotoxicity?}

Between 2 and 3\% of circulating erythrocytes of adults are "F-cells", erythrocytes containing detectable $\mathrm{HbF}[37,38]$. Erythroid progenitors often have high levels of $\mathrm{HbF}[39,40]$. Rapid expansion of the erythroid marrow induces F-cell production, suggesting that the kinetics of erythroid regeneration determine whether a red cell will become an F-cell[41]. Early erythroid progenitors may maintain the capacity for $\gamma$-globin gene expression, but with differentiation, this "program" is changed, permitting only adult globin gene expression[39,40]. Perhaps earlier progenitor cells contain transacting factors - fetal erythroid Krüppel-like factor is one example[42] - that favor $\gamma$-globin gene expression, while late progenitors express other transacting factors - erythroid Krüppel-like factor for example - that favor $\beta$-globin gene expression[42,43,44]. Cytotoxic agents kill late erythroid progenitor cells, triggering rapid erythroid regeneration and inducing F-cell formation[45]. Accelerated erythropoiesis increases the chance of premature commitment to differentiation resulting in enhanced production of Fcells. Hydroxyurea is an example of a drug thought to increase $\mathrm{HbF}$ levels because of its cytotoxicity. 


\section{Pharmacology}

Hydroxyurea is a ribonucleotide reductase inhibitor and an S-phase-specific cytotoxic agent. Well absorbed orally, it is converted in vivo to a free radical nitroxide that quenches the tyrosyl free radical at the active site of the M2 subunit of ribonucleotide reductase, the enzyme converting ribonucleotides to deoxyribonucleotides[46]. A potent inhibitor of DNA synthesis in cell culture and in organisms from viruses to man, to a lesser degree, hydroxyurea also inhibits RNA and protein synthesis and inhibits DNA repair[47]. Hydroxyurea has a volume distribution equal to body water, with peak serum concentrations reached in 3 to $6 \mathrm{~h}[47,48]$. From 45 to $70 \%$ was excreted unchanged in urine, with a variable amount excreted as urea[47]. In the presence of reduced pyridine nucleotide, hydroxyurea was converted to urea in liver and kidney of mice as a direct reduction catalyzed by enzymes present in most subcellular fractions of liver homogenates[49,50]. Besides the urea pathway, hydroxyurea was also reported to be metabolized into genotoxic products by cytochrome P-450-dependent monoxygenases[51]. Hydroxylamine may be rapidly methylated by acetyl-coenzyme A, producing acetohydroxamic acid, a metabolite found in blood of patients given hydroxyurea that may account for up to $10 \%$ of the drug administered[52].

Resistance to hydroxyurea occurs by several mechanisms in bacteria and in cell lines. Included are: overproduction of the B2 protein of ribonucleotide reductase; amplification of the M2 gene; increased translational efficiency of M2 mRNA; increased levels of M1 protein; prolonged half life of M1 and M2 subunits; increased M1 and M2 gene copy numbers; production of a resistant mutant enzyme[53]. Similar mechanisms of hydroxyurea resistance have the potential for modulating this agent's effects on erythropoiesis and $\mathrm{HbF}$ stimulation.

\section{Clinical Studies in Sickle Cell Anemia}

Hydroxyurea increased $\mathrm{HbF}$ level in anemic primates[54]. In sickle cell anemia, hydroxyurea increased F-reticulocytes (HbF-containing immature red cells) and $\mathrm{HbF}$ concentration with little short-term toxicity[55,56,57,58]. A multicenter trial of hydroxyurea (MSH) in 299 adults with sickle cell anemia, showed that hydroxyurea reduced the incidence of pain and acute chest syndrome by nearly half; during 9 years of observation, little risk was associated with taking this drug[59].

After 2 years of treatment, adult patients in the MSH had an increase in $\mathrm{HbF}$ from a baseline of $5 \%$ to about $9 \%[59]$. HbF increased to a mean of $18 \%$ in the top quartile of HbF response and to $9 \%$ in the next-best quartile, but changed little in the lower two quartiles of $\mathrm{HbF}$ response[60]. These results may not reflect what might be expected in all sickle cell anemia patients treated with this drug, since the patients selected for this study were "older" adults who had severe disease and were treated with escalating doses of drug to the brink of myelotoxicity. Not all patients reached the "maximal tolerated dose" specified in the protocol, since the study was stopped prematurely because of the beneficial effects of treatment[61]. Moreover, children appear to have a better $\mathrm{HbF}$ response than adults. Perhaps their bone marrow contains more HbFproducing progenitors and is better able to withstand myelotoxicity; they may also be more apt to comply with treatment.

Treatment was associated with less hemolysis, reflected by increased iron clearance, reduced reticulocyte count and plasma iron turnover, and increased total hemoglobin concentration[62]. Some patients had improved physical capacity, with improved anaerobic muscular performance and aerobic cardiovascular fitness[63]. Annual mean costs for painful episodes were $\$ 12,000$ for hydroxyurea-treated patients and $\$ 17,000$ for placebo-treated patients. When emergency department visits, costs of analgesics, and blood transfusion were included, the costs were $\$ 16,800$ for hydroxyurea-treated and $\$ 22,000$ for placebo-treated patients. 
Studies of hydroxyurea in infants, children, and adolescents with sickle cell anemia lag in the rigorous appraisal of clinical efficacy[64,65,66,67,68]. In 93 children and young adult patients treated with hydroxyurea for a median of 3.5 years, the number of hospitalizations and days hospitalized dropped significantly during treatment[69]. About half the treated patients followed for 5 years did not experience any vaso-occlusive events or require hospitalization.

On average, in younger patients $\mathrm{HbF}$ increased from $5 \%$ before treatment to $16 \%$ after 6 months to 1 year of treatment, hemolysis and neutrophil counts decreased, and short-term toxicity was minor[70]. Among 84 children, ages 5 to 15 years (mean age $\sim 10$ years), 68 reached the maximally tolerated dose and 52 completed 1 year of treatment[71]. About $20 \%$ of enrolled patients were withdrawn from the study, predominantly because of lack of compliance. At baseline, mean $\mathrm{HbF}$ was $6.8 \%$, and at the maximally tolerated dose levels increased to $19.8 \%$, with a range of 3.2 to $32.4 \%[72]$. Further analysis of this data suggested that the HbF levels achieved during treatment were associated with baseline $\mathrm{HbF}$ level, hemoglobin level, reticulocyte count and leukocyte count, and with treatment compliance[73]. In the MSH, baseline $\mathrm{HbF}$ was not associated with $\mathrm{HbF}$ levels during treatment, but this study looked at changes in $\mathrm{HbF}$ rather than $\mathrm{HbF}$ at the maximal tolerated dose[60].

In the youngest children and infants, few results have been reported[74,75]. HbF levels and hemoglobin concentration were increased or maintained. Reliable information on the potential for neurotoxicity and delayed growth in infants with sickle cell anemia given hydroxyurea is lacking, and this absence has hampered studies in this age group. While studies in young mice suggest the possibility of central nervous system damage, it is difficult to extrapolate these results to children; adverse effects on growth and development have not been noticed in children, although the age of patients treated so far may exceed the age of maximal injury potential[76].

We do not presently know whether hydroxyurea will prevent or reverse the organ damage accumulated during the course of sickle cell disease. After 1 year of treatment, splenic function in children with an average age of 12 years did not change[67]. In other studies of children, some appeared to recover or maintain splenic function[75,77]. Splenic regeneration was seen in two adults with sickle cell anemia who had $\mathrm{HbF}$ levels of about $30 \%$ after hydroxyurea treatment[78,79]. In another preliminary report, sickle pulmonary disease advanced despite a good hematological response to hydroxyurea[80]. Hydroxyurea did not appear to prevent the cerebrovascular complications of sickle cell anemia (see below).

\section{Clinical Studies in HbSC Disease and HbS- $\beta$ Thalassemia}

Pilot studies of hydroxyurea have been carried out in HbSC disease, the second most prevalent genotype of sickle cell disease. Selected hematologic findings in 14 patients with HbSC disease treated with hydroxyurea are shown in Table 1. Cell density fell, as reflected by absolute numbers of erythrocytes and reticulocytes with density $>38 \mathrm{~g} / \mathrm{dl}$. Pretreatment $(0.9 \pm 0.8)$ and final $(1.9 \pm$ $2.0 \%) \mathrm{HbF}$ levels were not statistically different; an increase in $\mathrm{HbF}$ from 1.7 to $6.7 \%$ in one patient accounted for the difference in the mean $\mathrm{HbF}$ level. An increased mean corpuscular volume (MCV), decreased serum bilirubin and reticulocyte count, and an increase in total hemoglobin level suggested reduced hemolysis[81,82]. Twenty-five patients with HbSC disease treated with hydroxyurea have been reported (Table 2) $[81,82,83,84]$. In one study, patients were selected for severe disease using criteria similar to those of the MSH[84]. In this uncontrolled trial, patients had 21 admissions per year before treatment, compared with 5 admissions per year after treatment. Based on our understanding of the pathophysiology of HbSC disease, reduced numbers of dense cells and a diminished polymerization tendency of HbS should modulate the phenotype of this disease, but no clinical trials have objectively studied the effectiveness of hydroxyurea in this disorder. 
TABLE 1

Selected Hematologic Data in Patients with HbSC Disease Treated with Hydroxyurea

$\begin{array}{ccccccc} & \text { PCV } & \text { MCV (fl) } & \text { rbcHb/rHb } & \text { Retic }\left(10^{9} / \mathrm{l}\right) & \begin{array}{c}\text { “Stress" } \\ \text { Retic }\left(10^{9} / \mathrm{l}\right)\end{array} & \begin{array}{c}\text { RBC }>1.112 \\ \left(10^{12} / \mathrm{l}\right)\end{array} \\ \text { Patients } & \begin{array}{c}\text { pre } \\ \text { post }\end{array} & \text { pre } & \text { pre } & \text { pre } & \text { pre } & \text { pre } \\ & & & \text { post } & \text { post } & \text { post } & \text { post } \\ 14 & 32.8 & 75.1 & 28.4 & 177 & 17.4 & 5.9 \\ & 34.6 & 84.5 & 39.0 & 122 & 8.6 & 0.12\end{array}$

Note: Counts were obtained using an $\mathrm{H}^{*} 3$ cell counter. $\mathrm{RBC}$ density was measured by phthalate ester gradient centrifugation. Differences between pre- and posthydroxyurea values were all significant $(p<.0 .05)$.

TABLE 2

Hematologic Findings in 25 Patients with HbSC Disease Treated with Hydroxyurea

$\begin{array}{ccccc} & & \text { PCV } & \text { MCV } & \text { HbF } \\ \text { Patient No. } & \text { Age (years) } & \text { pre } & \text { pre } & \text { pre } \\ 25 & & \text { post } & \text { post } & \text { post } \\ & 8-30 & 32 & 78 & 1.4 \\ & & 34 & 95 & 5.6\end{array}$

Note: These data summarize 4 studies of patients of different ages, treated with different doses of hydroxyurea for different time periods.

In HbS- $\beta$ thalassemia, hydroxyurea appears to work as well as in sickle cell anemia[85,86,87]. In a trial in Greeks with $\mathrm{HbS}-\beta^{0}$ thalassemia and $\mathrm{HbS}-\beta^{+}$thalassemia, $\mathrm{HbF}$ responses were higher than in African-Americans with sickle cell anemia, rising to $23 \%$ from the baseline of $3.6 \%$. Twenty-two Sicilians with severe HbS- $\beta$ thalassemia had an increase in $\mathrm{HbF}$ from 7.5 to $25 \%$ without reported complications[87]. In both trials, the numbers of patients treated were small and the studies were uncontrolled, but pain episodes were said to nearly stop. Most black patients with $\mathrm{HbS}-\beta^{+}$ thalassemia have 20 to $30 \% \mathrm{HbA}$ and a mild disease not warranting hydroxyurea treatment.

\section{Principles of Treatment}

Indications for hydroxyurea treatment are likely to change as our understanding of drug safety and benefits evolve. Painful episodes that occur at least twice a year and require parenteral opioids, recurrent acute chest syndrome, severe, symptomatic anemia, and perhaps other severe vaso-occlusive complications like priapism are the main indications for starting treatment. Presently, hydroxyurea should be reserved for adults and teenagers with sickle cell anemia or $\mathrm{HbS}-\beta^{0}$ thalassemia who can comply with the treatment regimen and whose complications are sufficiently severe to warrant the burdens of treatment. Severely effected patients with HbSC disease might be given a trial of treatment with the understanding that controlled studies showing a benefit of hydroxyurea in this genotype have not been reported. In young children with sickle 
cell anemia, outside the context of controlled trials, consultation with expert pediatricians and a detailed explanation to parents of the unknown attributes of this treatment and alternative treatments should precede therapy.

Several reports suggest hydroxyurea as an alternative to transfusion to prevent new or recurrent strokes, especially when transfusions are not feasible[88,89,90]. A child with HbSD disease was treated with hydroxyurea after several strokes and carotid bypass surgery[91]. He reached a $\mathrm{HbF}$ level of $30 \%$ and, during 28 months of follow-up, had regression of neurologic findings and no further stroke. Of 16 children given hydroxyurea to prevent recurrent strokes, 3 had a new neurological event early during treatment before $\mathrm{HbF}$ response was maximized[90]. Other instances of stroke in patients with sickle cell anemia treated with hydroxyurea, who had $\mathrm{HbF}$ levels that most would deem "therapeutic", have been recorded[92]. Little information on the distribution of $\mathrm{HbF}$ among erythrocytes in these instances - or in most cases of hydroxyurea treatment of sickle cell anemia - or the concentration of $\mathrm{HbF} / \mathrm{F}$-cells is available, but in one study F-cells averaged $60 \%$ with a high of $80 \%[68]$. If these cells all contained $\mathrm{HbF}$ concentrations sufficient to prevent cellular damage, the effects of this level of $\mathrm{HbF}$ should be equivalent to a transfusion where $80 \%$ of cells are incapable of sickling and only $20 \%$ of cells were HbS-cells. Why high $\mathrm{HbF}$ levels in hydroxyurea-treated patients with sickle cell anemia do not absolutely protect from stroke is unknown. HbF levels of $20 \%$ do not protect absolutely from other disease events, and perhaps stroke is no exception, just a more dramatic example of the shortcomings of a treatment that does not affect the entirety of the pathobiology of sickle cell disease. Alternatively, the pathogenesis of cerebral vasculopathy may differ from that of other vaso-occlusive complications and might not be responsive to the beneficial effects of increasing $\mathrm{HbF}$ concentration. Intracerebral hemorrhage, the main cause of stroke in adult sickle cell anemia, occurs at a rate of about $1 / 400$ patient years[93,94]. The MSH trial should be able to detect a doubling in the incidence of intracerebral hemorrhage, but no association of stroke with hydroxyurea was found[95].

Some patients have myelotoxicity at quite low doses, so there is no urgency to arrive rapidly at a final dose. Therapy can be started with 10 to $15 \mathrm{mg} / \mathrm{kg}$ given in a single daily dose, or adults can be started on $500 \mathrm{mg}$ daily. With the availability of 200-, 300-, and 400-mg hydroxyurea capsules (Droxia ${ }^{\mathrm{TM}}$ ), it is possible to more precisely titrate the dose of hydroxyurea. Rare adult patients cannot tolerate a $500 \mathrm{mg}$ daily dose. After 6 to 8 weeks, if blood counts are stable, the dose may be increased. Most patients who respond to hydroxyurea maintain tolerable blood counts at doses between 1,000 and 2,000 $\mathrm{mg}$ daily (20 to $30 \mathrm{mg} / \mathrm{kg}$ ). Many different dosing schemes have been recommended, but the sole controlled study gave drug daily and pushed the dose just short of toxicity[61]. Experience has suggested that dose escalation to subtoxic levels is not needed for a satisfactory therapeutic effect in most patients. The therapeutic endpoint should strike a balance between nontoxic doses of hydroxyurea and increases of HbF. Since MCV rises when hydroxyurea is used and usually parallels the increase in $\mathrm{HbF}$, this inexpensive measurement is a useful surrogate for $\mathrm{HbF}$ level that can be serially followed. Nevertheless, the concordance between $\mathrm{HbF}$ and $\mathrm{MCV}$ is not perfect, and $\mathrm{HbF}$ should be measured at baseline and 6- to 8-week intervals during the first 6 months of treatment.

Blood transfusions suppress erythropoiesis, and active erythropoiesis is necessary for hydroxyurea to increase $\mathrm{HbF}$. Although not carefully studied, using this agent in patients on frequent or regular transfusion programs is probably not efficacious, although preliminary reports suggested that some chronically transfused children may have a modest $\mathrm{HbF}$ increase when also receiving hydroxyurea[96,97].

Until a stable dose is achieved, blood counts should be monitored biweekly. Even when the final dose is reached, counts should be checked at 4- to 8-week intervals to forestall complications from capricious drops in leukocyte or platelet counts, some of which may be unrelated to treatment. Some adult patients will not respond to treatment with an increase in $\mathrm{HbF}$ or $\mathrm{MCV}$, even when they faithfully take their prescribed medication, although failure to take the 
medication regularly seems to account for the largest number of "poor responders" $[60,98,99]$. True "nonresponders" may number between 10 and $20 \%$ of treated patients. A response may depend on the dosing regimen, condition of the bone marrow, genetic determinants, and drug metabolism (see below)[60]. Patients should be explicitly counseled that: not everyone will respond; response differs among patients; many months may be needed to find the best dose of drug; medication must be taken exactly as directed, with frequent blood tests; the long-term toxicities and effects of treatment are unknown[100]. If a patient has not received blood transfusions or had an intercurrent illness that suppresses erythropoiesis, a 6- to 12-month trial should be sufficient to know if hydroxyurea will be an effective treatment, although longer times to response have been noticed.

\section{Combination Therapy with Hydroxyurea, Erythropoietin, Other Cytokines, and Butyrate}

Combination chemotherapy, akin to that used in cancer treatment, has the attraction of combining more than one drug, each with a separate effect on $\mathrm{HbF}$ synthesis and with nonoverlapping toxicities. Erythropoietin was given with hydroxyurea in nonhuman primates and caused an additive rise in $\mathrm{HbF}$ levels[101,102,103]. In a study of two baboons that were made chronically anemic by phlebotomy but were iron sufficient, either hydroxyurea or erythropoietin alone caused a 64 to $283 \%$ increment in F-reticulocytes above baseline. Combination therapy with both agents increased F-reticulocytes 150 to 383\%[102]. This work suggested that erythropoietin might be combined with agents that cause cytoreduction and rapid erythroid regeneration to achieve a synergistic effect. A study of erythropoietin and hydroxyurea was associated with increases in $\mathrm{HbF}$ beyond those seen with hydroxyurea alone[85,104,105]. Four patients with sickle cell anemia who did not respond to butyrate alone were treated with both hydroxyurea and butyrate. Three increased their $\mathrm{HbF}$ concentrations from about 1 to $24 \%[106]$. These interesting preliminary results argue for more careful study of this drug combination.

Other cytokines, including c-kit ligand (stem cell factor), GM-CSF, and IL-3 may elevate $\mathrm{HbF}$ in primates and in erythroid cell cultures, including cultures derived from patients with sickle cell disease[107], but neither GM-CSF nor IL-3 appear to work synergistically with hydroxyurea. Moreover, a potential to increase greatly the neutrophil count may preclude the use of GM-CSF and IL-3 in sickle cell anemia and in other severe $\beta$-globin gene disorders where activated granulocytes may adversely affect the course of disease[101]. When stem cell factor was used in conjunction with hydroxyurea and erythropoietin in baboons, an increment in $\mathrm{HbF}$ was observed, compared with stem cell factor and erythropoietin alone[108]. Some treatment regimens caused the leukocyte count to increase acutely and dramatically, so that clinical utility of combinations including stem cell factor is questionable.

In vitro studies using a sophisticated method of obtaining sibling BFU-e measured F-cells and $\gamma$-globin chains after exposure of erythroid clones to Il-3, GM-CSF, and c-kit ligand. While Il-3 and GM-CSF caused a 2- to 4-fold increase in F-cells and $\gamma$-globin chains, c-kit ligand was associated with an increase of 20 -fold that was further enhanced by the addition of sodium butyrate[109]. The effect of c-kit on F-cells was accompanied by increased expression of the Tal1 and FKLF genes that may play a regulatory role in $\gamma$-globin gene expression. Transforming growth factor $\beta$ (TGF $\beta$ ) increased the proportions F-cells during the first 4 days of in vitro culture, an increase not dependent on combinations of erythropoietin, c-kit ligand, and IL-3. During continued growth, the number of F-cells in TGF $\beta$-treated cultures was approximately tenfold higher than in controls[110]. 


\section{Adverse Effects}

After more than 9 years of observation, little risk was associated with the careful use of hydroxyurea[95]. Yet, hydroxyurea must be taken indefinitely to be effective and is potentially mutagenic and carcinogenic.

Cellular changes that may antedate neoplastic transformation, like increases in chromosome breakage, recombination events, or mutations in the hprt genes, have not yet been found in hydroxyurea-treated sickle cell anemia patients compared with controls[111]. A study was done of hprt gene mutations and "illegitimate" recombination events between the $\beta$ and $\gamma$ gene loci of the T-cell receptor in adults with sickle cell anemia exposed to hydroxyurea for 24 months, children with sickle cell anemia exposed for 7 or 30 months, and adults with myeloproliferative disorders exposed for 11 years. Children who were exposed to hydroxyurea for 30 months had more recombination events $(1.8 \pm 1.2)$ compared with children with 7 months of drug exposure $(1.6 \pm 0.9)$ and children unexposed to drug $(1.1 \pm 0.5)$. No other differences in DNA mutations were found between these groups and unexposed matched controls or normal adults, suggesting to the authors that the leukemogenic potential of the drug is low[111].

Two study patients in the MSH developed cancer[95]. One individual who took hydroxyurea for 63 months had cervical carcinoma in situ. Another patient with 47 months of exposure to hydroxyurea had a history of fibrocystic breast disease, and multifocal carcinoma in situ was found in prophylactic bilateral mastectomy specimens. Hydroxyurea was used for more than 5 years to decrease PCV in children with cyanotic congenital heart disease without any reports of malignancies, but only 64 patients were followed[112].

Between 5 and $10 \%$ of patients with the myeloproliferative disorders polycythemia vera and essential thrombocythemia, who received hydroxyurea, developed acute leukemia[113-120]. This risk rate may not be the same in patients with sickle cell anemia. Two reports of patients with sickle cell anemia treated with hydroxyurea who developed acute leukemia have been published (other cases are known but unpublished) but the total number of patients treated is unknown[121,122]. If the baseline rate of leukemia and cancer in adults with sickle cell anemia is similar to that observed in the general population, a not unreasonable assumption at this time[123,124], because of its size and length of follow-up, the MSH only has power to detect hundredfold increases in the incidence of neoplasia. MSH data suggests that the relative risk of leukemia in patients with sickle cell anemia treated with hydroxyurea is much less than that observed in myeloproliferative disorders and that the risk of death from the complications of sickle cell disease is at least ten times greater than the incidence of leukemia in these patients.

Hydroxyurea is a teratogen in rats, cats, and rhesus monkeys and should not be used if pregnancy is planned. Pregnancy has been reported, in at least 16 women receiving hydroxyurea; most had myeloproliferative disorders but 6 had sickle cell anemia[59,125,126]. Adverse outcomes in this small series did not occur. Contraception should be practiced by both women and men receiving hydroxyurea, and the uncertain outcome of an unplanned pregnancy should be discussed frankly. If a patient who is taking hydroxyurea becomes pregnant, little information is available on which to base a decision for continuation or termination.

Pigmentation of the nails and localized increase in skin pigmentation have been observed and may disappear despite continued treatment[127]. Leg and oral ulcers have been reported in patients with myeloproliferative diseases treated with hydroxyurea[128,129,130,131]. Ankle ulcers were seen when these patients received hydroxyurea for an average of 6 years. They healed when the drug was stopped but recurred when it was restarted. Of 17 adults with sickle cell disease given hydroxyurea for a mean of 3 years, $30 \%$ developed leg ulcers, but $80 \%$ of these patients had ulcers before[132]. This extremely high incidence of leg ulcers was not seen in the MSH, where hydroxyurea had no effect of on healing or occurrence of leg ulcers. Compared with the observations in myeloproliferative diseases, the follow-up interval in sickle cell anemia on hydroxyurea is short. 


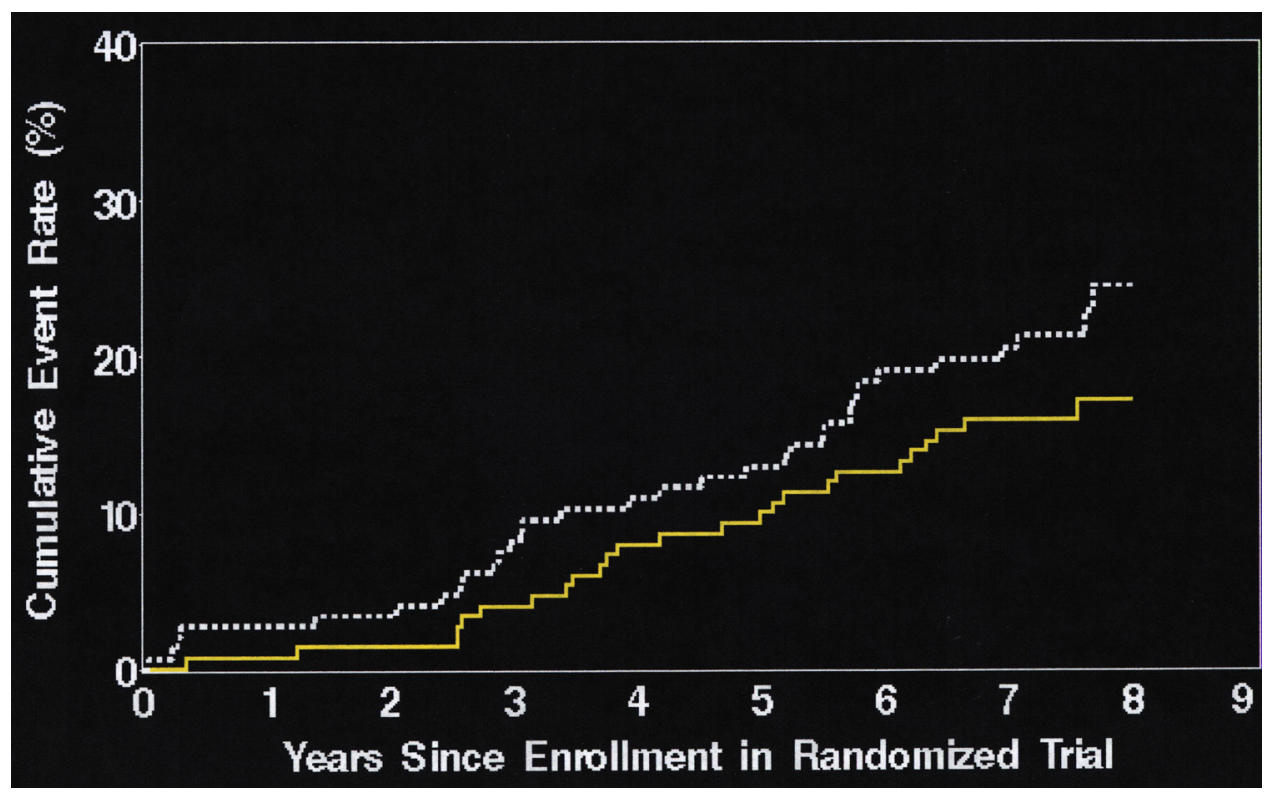

FIGURE 1. Cumulative mortality of patients originally randomized to receive hydroxyurea (yellow line) or a placebo (white line). Randomized treatment stopped after 2.5 years. The differences in mortality, when analyzed by original treatment assignment were not significant.

\section{Prognosis during Treatment}

Patients in the MSH trial participated in a long-term follow-up study where treatment with hydroxyurea was elective. After nearly 10 years of observation, $25 \%$ of patients who volunteered for the MSH had died, reflecting severe disease - a criteria for study enrollment — and the high death rate in adult sickle cell anemia (Fig. 1)[133]. Of these deaths, 30\% were due to pulmonary complications. Cumulative mortality was analyzed by (1) original treatment assignment, (2) $\mathrm{HbF}$ level, (3) reticulocyte count, (4) hemoglobin concentration, (5) neutrophil count, (6) painful episode frequency, and (7) occurrence of acute chest syndrome. In 278 patients who had $\mathrm{HbF}$ measured about 2 years into the $\mathrm{MSH}$, patients with $\mathrm{HbF}<0.5 \mathrm{~g} / \mathrm{dl}$ had a $28 \%$ cumulative mortality through 9 years, compared with $15 \%$ mortality in patients whose $\mathrm{HbF}$ was $\geq 0.5 \mathrm{~g} / \mathrm{dl}$ (Fig. 2). Before treatment, $68 \%$ of hydroxyurea and $65 \%$ of placebo-randomized patients had $\mathrm{HbF}$ of $<0.5 \mathrm{~g} / \mathrm{dl}$. When the trial was completed, $38 \%$ of the hydroxyurea-randomized patients with initial $\mathrm{HbF}<0.5 \mathrm{~g} / \mathrm{dl}$ had $\mathrm{HbF} \geq 0.5 \mathrm{~g} / \mathrm{dl}$. In contrast, only $8 \%$ of placebo-treated patients with baseline $\mathrm{HbF}<0.5 \mathrm{~g} / \mathrm{dL}$ had final $\mathrm{HbF} \geq 0.5 \mathrm{~g} / \mathrm{dl}$. Neutrophil counts before random assignment and treatment and at the end of the clinical trial also did not predict mortality. Patients with absolute reticulocyte counts $<2.5 \times 10^{5} / \mathrm{ml}$ after 2 years of treatment had a cumulative mortality of $37 \%$, compared with $18 \%$ in individuals with $\geq 2.5 \times 10^{5}$ reticulocytes $/ \mathrm{ml}$. In a subgroup of 61 patients with reticulocyte counts $<2.5 \times 10^{5} / \mathrm{ml}$ and hemoglobin concentrations $<9$ $\mathrm{g} / \mathrm{dl}$, cumulative mortality was increased after 9 years of observation. These individuals also had lower $\mathrm{HbF}$ levels and higher serum creatinine levels and were receiving lower doses of hydroxyurea, compared with other patient groups. Patients without any episodes of acute chest syndrome during the trial had a mortality of $20 \%$, compared with $34 \%$ in patients who had one of more acute chest episodes. Individuals with fewer than three annual painful episodes during the clinical trial had a mortality of $19 \%$, compared with $28 \%$ in patients with three or more painful episodes annually. Mortality was reduced during 3-month intervals when patients were taking hydroxyurea, from an average of $2.6 \pm 5.8$ deaths $/ 3$-month period to $1.5 \pm 7.9$ deaths $/ 3$ months (Fig. 3). 


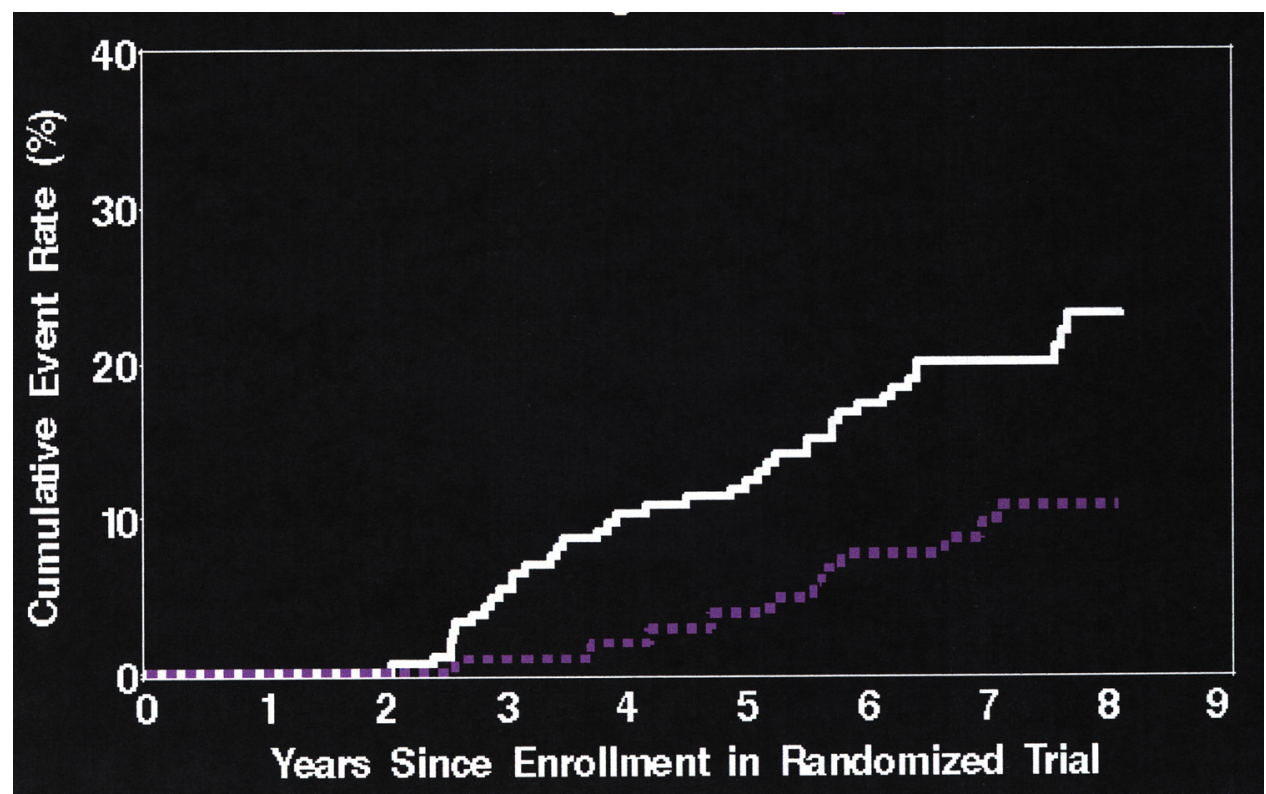

FIGURE 2. Cumulative mortality according to $\mathrm{HbF}$ levels after the conclusion of the randomized portion of the MSH. White line represents patients with $\mathrm{HbF}<0.5 \mathrm{~g} / \mathrm{dL}$ and lavender line patients with $\mathrm{HbF}>0.5 \mathrm{~g} / \mathrm{dL}(p=0.03)$.

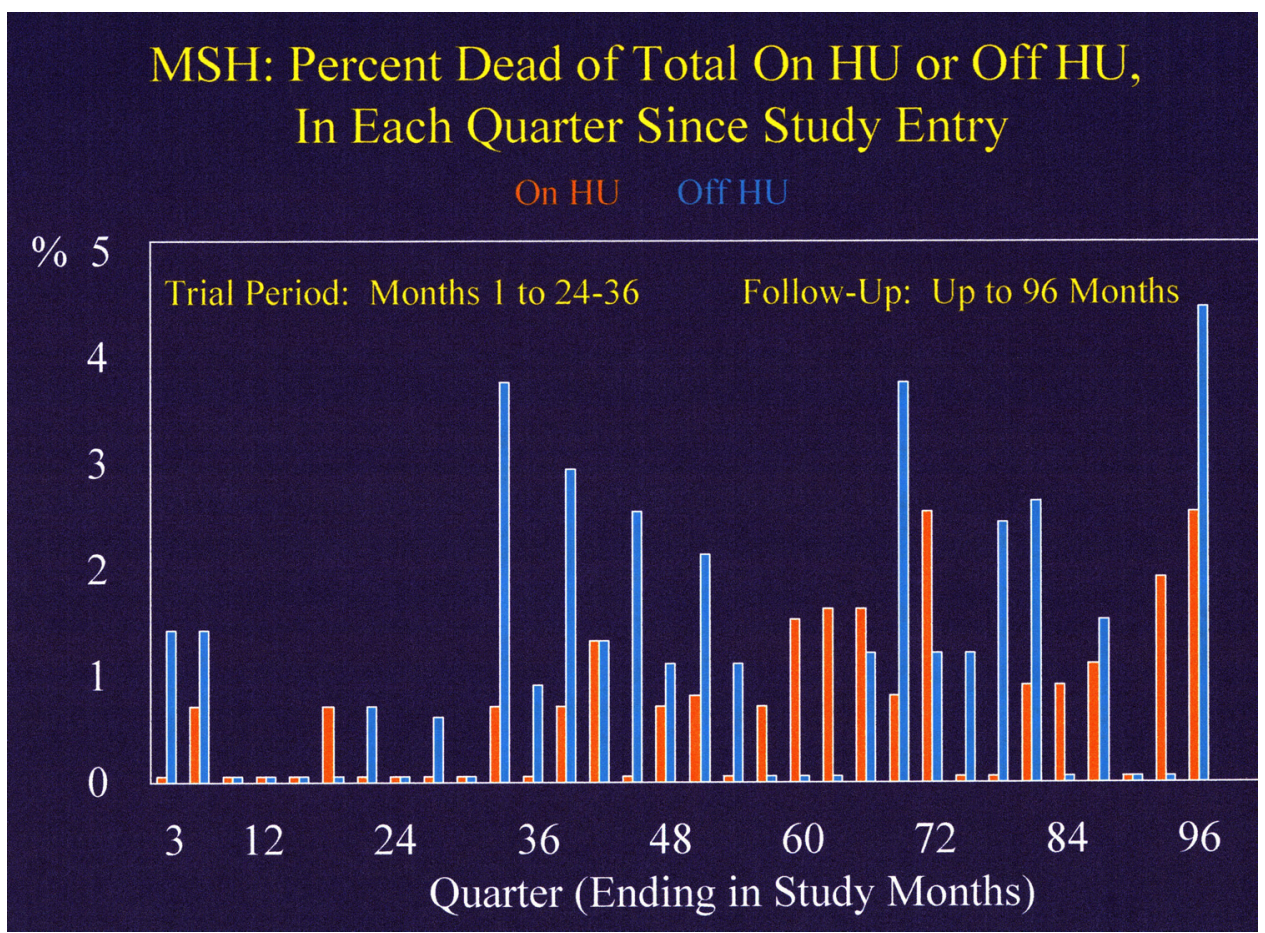

FIGURE 3. Mortality by 3-month intervals in patients taking (blue bars) or not taking (orange bars) hydroxyurea. Patients on hydroxyurea had reduced mortality $(p=0.04)$.

These studies suggest that adults with moderate to severe sickle cell anemia who take hydroxyurea have reduced mortality compared with patients not taking this drug. During more than 9 years of observation the estimated overall reduction in mortality was $40 \%$. However, the comparisons of patients on and off hydroxyurea were no longer randomized, and assessment of 
the effect of hydroxyurea on mortality in an observational study is complex[81]. Nevertheless, the observation of reduced mortality associated with hydroxyurea is consistent with hydroxyurea reducing the incidence of pain and acute chest syndrome by nearly half[59].

\section{Non-HbF-Mediated Effects That Might Account for Clinical Effectiveness}

Hydroxyurea may work by multiple mechanisms, although a clinical benefit mediated through its effects on $\mathrm{HbF}$ concentration is supported by the strongest evidence. Indisputably, the increase in $\mathrm{HbF}$ is a primary effect of treatment, making it difficult to know if the other myriad effects are primary or secondary to increased $\mathrm{HbF}$. While some erythrocyte changes are seen before total $\mathrm{HbF}$ concentration is increased, this does not exclude changes in $\mathrm{HbF}$ distribution among red cells or small unmeasurable changes in individual cells.

In most open-label trials, improvement in clinical symptoms mirrored - even slightly preceded - the increases in measurable HbF levels. Further studies suggested that the reduction in neutrophils, monocytes, and reticulocytes may also be important[134]. Neutrophils from patients having a painful episode had increased adherence to cultured endothelial cells and expressed higher levels of CD64, an epitope than may promote vascular adherence[135]. By reducing blood neutrophils, hydroxyurea might lessen the chance of vaso-occlusive events.

"Stress" reticulocytes may initiate some vaso-occlusive events of sickle cell disease[136,137,138,139,140,141,142]. A reduction in the numbers of normal reticulocytes and "stress" reticulocytes occurred in sickle cell anemia and HbSC disease patients treated with hydroxyurea, and in sickle cell anemia, this reduction was correlated with the reduction in pain crises. In HbSC disease, hydroxyurea was associated with sustained erythrocyte volume increases and a fall in absolute reticulocyte counts, "stress" reticulocytes, and dense red cells, and this effect seemed to be independent of increases in $\mathrm{HbF}[81]$. During treatment, many simultaneous changes befall the sickle erythrocyte[143]. Sickle cell-endothelial cell adherence decreases before a measured increase in $\mathrm{HbF}$ occurs, suggesting a direct effect on red cell membrane or endothelial cell adhesive properties. In vitro, hydroxyurea may affect endothelial cells, changing their morphology and cation content and making them a less attractive site for sickle cell adherence[144]. Dense cell numbers fall as erythrocyte $\mathrm{K}^{+}$content increases[143]. Two reticulocyte adhesion receptors, $\alpha_{4} \beta_{1}$ intergrin, or the very late activation antigen (VLA)- 4 , and CD36, also fall early during hydroxyurea treatment before measurable increases in $\mathrm{HbF}[145]$. Improved cellular hydration and deformability are likely to be secondary to increased $\mathrm{HbF}$ and may play a role in the reduction of vaso-occlusive episodes and the reduced hemolysis accompanying treatment[146]. Steady-state soluble VCAM-1 levels are increased in sickle cell anemia compared with normal controls, and a significant decrease was found during treatment with hydroxyurea[147]. Treatment did not affect fibronectin levels or soluble neutrophil adhesion molecules.

In vitro studies of the adhesion of sickle erythrocytes to immobilized thrombospondin and laminin showed a $60 \%$ reduction in adhesion when patients with sickle cell anemia treated with hydroxyurea were compared with untreated controls[148]. When adhesion before and during treatment with hydroxyurea were compared, treatment was associated with a sustained fall in adhesion.

Other novel mechanisms of action of hydroxyurea have been proposed. Nitric oxide (NO), or endothelial derived relaxing factor, is a potent vasodilator. Peroxidation of hydroxyurea can generate $\mathrm{NO}[149,150,151]$. In rats, hydroxyurea leads to $S$-nitrosohemoglobin formation. Nitrosyl hemoglobin complex could be detected as early as $30 \mathrm{~min}$ and persisted up to $4 \mathrm{~h}$ after administration of hydroxyurea to patients with sickle cell anemia[152]. In one study, NO increased the $\mathrm{O}_{2}$ affinity of $\mathrm{HbS}$, reducing its polymerization potential, but these results have not been replicated[153,154]. In vitro studies have shown that $\mathrm{HbS}$ is also able to form sickle 
nitrosylhemoglobin and that the NO group of this modified molecule derives from the $\mathrm{NHOH}$ moiety of hydroxyurea[151]. Normally, $S$-nitrosohemoglobin is formed in the lung, while in tissues, NO is transferred to the vessel wall, promoting vasodilatation[155]. Perhaps hydroxyurea, by promoting NO-mediated vasodilatation, reduces the propensity for microvascular occlusion.

Preliminary studies have shown that hydroxyurea can induce methemoglobin formation and, perhaps, reduce deoxyHbS concentrations, but an early attempt to treat sickle cell anemia by inducing methemoglobinemia was unsuccessful[156,157]. Sickle, but not normal erythrocytes, incubated with hydroxyurea have reduced deformability, an adverse effect proposed to be due to methemoglobin formation[158]. While sickle ghosts and sickle cells incubated with $\mathrm{CO}$ were unaffected, methemoglobin levels were not measured.

Hydroxyurea was noted to increase erythropoietin production up to 30 -fold over baseline levels 2 to 10 days after beginning treatment. It was hypothesized that this enhances the proliferation of erythroid precursors with the capacity to synthesize $\mathrm{HbF}[159]$.

\section{Predicting the HbF Response to Hydroxyurea}

Not every patient responds to hydroxyurea with an increased $\mathrm{HbF}$, and among responders, the $\mathrm{HbF}$ increment varies from minimal to more than tenfold[31]. Predicting who will respond to hydroxyurea treatment with an increase in $\mathrm{HbF}$ is a worthy goal that is not yet achievable in an individual patient. In 83 hydroxyurea-treated patients using 23 different parameters, correlation and linear regression analysis failed to predict the $\mathrm{HbF}$ response, but an artificial neural network pattern-recognition analysis predicted the response with $87 \%$ accuracy[160].

In the $\mathrm{MSH}$, the best $\mathrm{HbF}$ responses were seen in individuals with highest initial neutrophil and reticulocyte counts and the largest treatment-associated decrements in these counts. Patients with the greatest reduction in granulocyte, monocyte, and reticulocyte counts also had the largest reduction in painful episodes[134]. HbF levels and blood counts changed little from the baseline in poor responders[60]. Most patients responded initially to hydroxyurea with increased numbers of F-cells, but there was a divergence between patients who were long-term responders and those who did not sustain their F-cell response. Among patients with little change in $\mathrm{HbF}$ level, neutrophil and reticulocyte counts returned to baseline early during treatment and the percent Fcells decreased after an initial rise. Because of marrow "scarring", some patients may be unable to tolerate continued myelosuppressive doses of hydroxyurea[161,162].

Myelosuppression may be prerequisite for hydroxyurea-induced enhancement of $\mathrm{HbF}$ levels. Patients with the highest baseline granulocyte and reticulocyte counts - who also had the largest decreases in these counts during treatment - had the greatest increases in $\mathrm{HbF}$. In earlier studies, the initial leukocyte count and fall in leukocytes with treatment were also determinants of the final $\mathrm{HbF}$ levels after treatment with hydroxyurea[57]. Some patients - perhaps as many as 10 to $20 \%$ of all patients treated - did not respond to treatment or had a minor increase in $\mathrm{HbF}$. However, the dosing regimens, final dosages achieved, and length of treatment differed among studies[57,98]. Most patients who respond to treatment will have a response within 1 year of beginning treatment and drug titration.

Genetic elements that may be linked or unlinked to the $\beta$-like globin gene cluster may account for differences in $\mathrm{HbF}$ level and the $\mathrm{HbF}$ response to hydroxyurea. Individuals with the best $\mathrm{HbF}$ response were less likely to have a $\mathrm{HbS}$ gene on a Bantu haplotype chromosome[134]. The X-linked F-cell production locus phenotype was a determinant of baseline HbF levels, but did not predict the $\mathrm{HbF}$ response to hydroxyurea.

A search for polymorphisms in elements linked to the $\beta$-globin gene was undertaken to help explain the inconsistency of $\mathrm{HbF}$ response to hydroxyurea. Although polymorphisms in elements thought to be important regulators of gene transcription - a 520 base pair core of 5' hypersensitive site (HS)-II of the locus control region (LCR); the $(\mathrm{AT})_{\mathrm{x}}(\mathrm{T})_{\mathrm{y}}$ repeats $5^{\prime}$ to the $\beta$ - 
globin gene; a $0.5-\mathrm{kb}$ segment 5 ' to the ${ }^{\mathrm{G}} \gamma$ gene - existed in sickle cell anemia patients with different $\mathrm{HbF}$ levels, they and other phylogenetically conserved regions of the LCR were always linked to a particular $\beta$-globin gene cluster haplotype[60,163,164,165,166,167]. In "hybrid" haplotype $\beta^{\mathrm{S}}$ chromosomes from unselected sickle cell disease patients, the HS-II short tandem repeat (TA)xN10-12(TA)y differed from that typically associated with a cognate haplotype. Each of these "hybrid" chromosomes had a breakpoint upstream of the $0.5-\mathrm{kb}$ pre- ${ }^{\mathrm{G}} \gamma$ gene element, suggesting that variability in $\mathrm{HbF}$ level associated with polymorphisms of the HS-II enhancer depended on downstream cis-acting elements in tight linkage disequilibrium with HS-II[168]. Conserved noncoding DNA 5 ' to the $\beta$-globin gene cluster may also have important regulatory functions. While hypersensitive sites and their core sequences are conserved among mammalian genomes, percentage-identity plots of the human and mouse $\beta$-globin gene clusters showed that sequences outside the cores of hypersensitive sites were as conserved as the cores themselves. These regions also contributed to the ability of LCR DNA fragments to establish and/or maintain an open chromatin domain after stable integration into genomic DNA[169,170,171]. Phylogenetic conservation of some olfactory receptor genes and their flanking sequences $5^{\prime}$ to the LCR suggests that this region may also function to control gene expression within the $\beta$-globin genelike complex[172,173,174,175,176].

Twins with sickle cell disease had similar $\mathrm{HbF}$ levels whatever their disease phenotype[177,178]. Siblings with sickle cell disease are also likely to share identical $\beta$-globin genes with their associated regulatory regions. Therefore, a concordant $\mathrm{HbF}$ response to hydroxyurea treatment would suggest that the determinants of this response were, at least partially, linked to this gene cluster. The hematologic response to hydroxyurea was evaluated in siblings from 20 families with sickle cell anemia, including three families with three siblings and six families with HbS- $\beta$ thalassemia, including one family with three siblings and one pair of monozygotic twins. All patients with HbS- $\beta$ thalassemia were Greek. A high positive correlation between sibs was found for $\mathrm{HbF}$ and mean corpuscular volume (MCV). These observations were independent of the sex of siblings. While other genetic determinants of $\mathrm{HbF}$ level unlinked to the $\beta$-globin gene cluster exist[179,180,181,182,183], siblings with sickle cell disease are not as likely to share identical transacting factors as they are to share genetic elements linked to their $\beta$-globin gene complex. These data suggest that some genetic elements that control the HbF response to hydroxyurea are linked to the $\beta$-globin gene cluster. A search for these novel regulatory elements - perhaps in siblings with discordant HbF levels - may identify predictors of the HbF response to hydroxyurea and new targets for pharmacologic or gene therapy.

In summary, compliance with treatment, pretreatment $\mathrm{HbF}$ level, bone marrow "reserve", $\beta$ globin gene cluster haplotype, and behavior of erythroid precursors in culture may help predict who will have a favorable $\mathrm{HbF}$ response to treatment. But currently, none are sufficiently precise to be clinically useful[ $57,60,73,105,184,185]$.

\section{CONCLUSIONS}

The phenotype of sickle cell disease is largely dependent on HbS polymerization that, in a complex cascade of pathophysiology, results in damage to the sickle erythrocyte and endothelium. Safely "turning on" $\mathrm{HbF}$ genes early in childhood before $\mathrm{HbF}$ levels decline to a "subtherapeutic" concentration and vascular damage results, so that each sickle erythrocyte has about $20 \% \mathrm{HbF}$, should "cure" sickle cell anemia. Modulation of $\mathrm{HbF}$ production using hydroxyurea is a promising beginning for pharmacologic therapy of sickle cell disease. Still, in adults with sickle cell anemia, its effects are inconsistent, and the limit of increasing $\mathrm{HbF}$ with this agent alone may have been reached. Combination chemotherapy to increase $\mathrm{HbF}$ concentration has a sound conceptual base, but studies of its clinical effectiveness have not yet been done. Agents that prevent or reverse sickle cell 
dehydration might be added to decrease the cellular concentration of $\mathrm{HbS}$ and further retard $\mathrm{HbS}$ polymerization[186]. Adding to this, drugs that prevent the abnormal interactions of sickle cells with endothelium would target three of the dominant pathways implicated in propagating the multiple phenotypes of this disease[187].

\section{REFERENCES}

1. Watson, J., Stahman, A.W., and Bilello, P. (1948) Significance of paucity of sickle cells in newborn negro infants. Am. J. Med. Sci. 215, 419-423.

2. Steinberg, M.H. (2001) Compound heterozygous and other hemoglobinopathies. In Disorders of Hemoglobin: Genetics, Pathophysiology, and Clinical Management. Steinberg, M.H., Forget, B.G., Higgs, D.R., and Nagel, R.L., Eds. Cambridge University Press, Cambridge. pp. 786-810.

3. Edington, G.M. and Lehmann, H. (1955) Expression of the sickle-cell gene in Africa. Br. Med. J. 1, 13081311 .

4. Nagel, R.L., Bookchin, R.M., Labie, D., Wajcman, H., Isaac-Sadeye, W.A., and Honig, G.R. (1979) Structural basis for the inhibitory effects of hemoglobin $\mathrm{F}$ and hemoglobin A2 on the polymerization of hemoglobin S. Proc. Natl. Acad. Sci. U. S. A. 76, 670-672.

5. Benz, E.J., Jr. (1982) Clinical management of gene expression. N. Engl. J. Med. 307, 1515-1516.

6. Papayannopoulou, T., Torrealba de Ron, A., Veith, R., Knitter, G., and Stamatoyannopoulos, G. (1984) Arabinosylcytosine induces fetal hemoglobin in baboons by perturbing erythroid cell differentiation kinetics. Science 224, 617-619.

7. Veith, R., Papayannopoulou, T., Kurachi, S., and Stamatoyannopoulos, G. (1985) Treatment of baboon with vinblastine: insights into the mechanisms of pharmacologic stimulation of $\mathrm{Hb} F$ in the adult. Blood 66, 456459.

8. Felsenfeld, G. and McGhee, J. (1982) Methylation and gene control. Nature 296, 602-603.

9. van der Ploeg, L.H. and Flavell, R.A. (1980) DNA methylation in the human gamma delta beta-globin locus in erythroid and nonerythroid tissues. Cell 19, 947-958.

10. Garrick, D., Sutherland, H., Robertson, G., and Whitelaw, E. (1996) Variegated expression of a globin transgene correlates with chromatin accessibility but not methylation status. Nucleic Acids Res. 24, 49024909.

11. DeSimone, J., Heller, P., Hall, L., and Zwiers, D. (1982) 5-Azacytidine stimulates fetal hemoglobin synthesis in anemic baboons. Proc. Natl. Acad. Sci. U. S. A. 79, 4428-4431.

12. Charache, S., Dover, G., Smith, K., Talbot, C.C., Jr., Moyer, M., and Boyer, S.H. (1983) Treatment of sickle cell anemia with 5-azacytidine results in increased fetal hemoglobin production and is associated with nonrandom hypomethylation of DNA around the $\gamma-\delta-\beta$ globin gene complex. Proc. Natl. Acad. Sci. U.S.A. 80, $4842-4846$.

13. Ley, T.J., DeSimone, J., Noguchi, C.T., Turner, P.H., Schechter, A.N., Heller, P., and Nienhuis, A.W. (1983) 5-Azacytidine increases gamma-globin synthesis and reduces the proportion of dense cells in patients with sickle cell anemia. Blood 62, 370-380.

14. Humphries, R.K., Dover, G., Young, N.S., Moore, J.G., Charache, S., Ley, T., and Nienhuis, A.W. (1985) 5Azacytidine acts directly on both erythroid precursors and progenitors to increase production of fetal hemoglobin. J. Clin. Invest. 75, 547-557.

15. Koshy, M., Dorn, L., Bressler, L., Molokie, R., Lavelle, D., Talischy, N., Hoffman, R., van Overveld, W., and DeSimone, J. (2000) 2-deoxy 5-azacytidine and fetal hemoglobin induction in sickle cell anemia. Blood 96, 2379-2384.

16. Kruh, J. (1982) Effects of sodium butyrate, a new pharmacological agent on cells in culture. Mol. Cell. Biochem. 42, 65-82.

17. Ginder, G.D., Whitters, M.J., and Pohlman, J.K. (1984) Activation of a chicken embryonic globin gene in adult erythroid cells by 5-azacytidine and sodium butyrate. Proc. Natl. Acad. Sci. U. S. A. 81, 3954-3958.

18. Jenuwein, T. and Allis, C.D. (2001) Translating the histone code. Science 293, 1074-1080.

19. Glauber, J.G., Wandersee, N.J., Little, J.A., and Ginder, G.D. (1991) 5'-Flanking sequences mediate butyrate stimulation of embryonic globin gene expression in adult erythroid cells. Mol. Cell. Biol. 11, 4690-4697.

20. Pace, B.S., Li, Q.L., and Stamatoyannopoulos, G. (1996) In vivo search for butyrate responsive sequences using transgenic mice carrying Ay gene promoter mutants. Blood 88, 1079-1083.

21. Ikuta, T., Kan, Y.W., Swerdlow, P.S., Faller, D.V., and Perrine, S.P. (1998) Alterations in protein-DNA interactions in the gamma-globin gene promoter in response to butyrate therapy. Blood 92, 2924-2933.

22. Constantoulakis, P., Knitter, G., and Stamatoyannopoulos, G. (1989) On the induction of fetal hemoglobin by butyrates: in vivo and in vitro studies with sodium butyrate and comparison of combination treatments with 5-AzaC and AraC. Blood 74, 1963-1971. 
23. Perrine, S.P., Miller, B.A., Faller, D.V., Cohen, R.A., Vichinsky, E.P., Hurst, D., Lubin, B.H., and Papayannopoulou, T. (1989) Sodium butyrate enhances fetal globin gene expression in erythroid progenitors of patients with $\mathrm{Hb}$ SS and beta thalassemia. Blood 74, 454-459.

24. Perrine, S.P., Miller, B.A., Greene, M.F., Cohen, R.A., Cook, N., Shackleton, C., and Faller, D.V. (1987) Butyric acid analogues augment $\gamma$ globin gene expression in neonatal erythroid progenitors. Biochem. Biophys. Res. Commun. 148, 694-700.

25. Perrine, S.P., Ginder, G.D., Faller, D.V., Dover, G.H., Ikuta, T., Ewa Witkowska, H., Cai, S., Vichinsky, E.P., and Olivieri, N.F. (1993) A short-term trial of butyrate to stimulate fetal-globin-gene expression in the $\beta$-globin disorders. N. Engl. J. Med. 328, 81-86.

26. Sher, G.D., Ginder, G.D., Little, J., Yang, S., Dover, G.J., and Olivieri, N.F. (1995) Extended therapy with intravenous arginine butyrate in patients with $\beta$-hemoglobinopathies. N. Engl. J. Med. 332, 1606-1610.

27. Dover, G.J., Brusilow, S., and Charache, S. (1994) Induction of fetal hemoglobin production in subjects with sickle cell anemia by oral sodium phenylbutyrate. Blood 84, 339-343.

28. Blau, C.A., Constantoulakis, P., Shaw, C.M., and Stamatoyannopoulos, G. (1993) Fetal hemoglobin induction with butyric acid: efficacy and toxicity. Blood 81, 529-537.

29. Boosalis, M.S., Bandyopadhyay, R., Bresnick, E.H., Pace, B.S., Van DeMark, K., Zhang, B., Faller, D.V., and Perrine, S.P. (2001) Short-chain fatty acid derivatives stimulate cell proliferation and induce STAT-5 activation. Blood 97, 3259-3267.

30. Atweh, G.F., Sutton, M., Nassif, I., Boosalis, V., Dover, G.J., Wallenstein, S., Wright, E., McMahon, L., Stamatoyannopoulos, G., Faller, D.V., and Perrine, S.P. (1999) Sustained induction of fetal hemoglobin by pulse butyrate therapy in sickle cell disease. Blood 93, 1790-1797.

31. Steinberg, M.H. and Rodgers, G.P. (2001) Pharmacologic modulation of fetal hemoglobin. Medicine (Baltimore) 80, 328-344.

32. Resar, L., Fitzpatrick, L.K., Friedmann, A.M., Brusilow, S., and Dover, G.J. (1999) Induction of fetal hemoglobin synthesis in children with sickle cell anemia on oral sodium phenylbutyrate. Blood 94, 417a.

33. Collins, A.F., Dover, G.J., and Luban, N.L.C. (1994) Increased fetal hemoglobin production in patients receiving valproic acid for epilepsy. Blood 84, 1690-1691.

34. Selby, R., Nisbet-Brown, E., Basran, R.K., Chang, L.B., and Olivieri, N.F. (1997) Valproic acid and augmentation of fetal hemoglobin in individuals with and without sickle cell disease. Blood 90, 891-893.

35. Dover, G.J., Brusilow, S., and Samid, D. (1992) Increased fetal hemoglobin in patients receiving sodium 4phenylbutyrate. N. Engl. J. Med. 327, 569-570.

36. Little, J.A., Dempsey, N.J., Tuchman, M., and Ginder, G.D. (1995) Metabolic persistence of fetal hemoglobin. Blood 85, 1712-1718.

37. Boyer, S.H., Belding, T.K., Margolet, L., and Noyes, A.N. (1975) Fetal hemoglobin restriction to a few erythrocytes (F cells) in normal human adults. Science 188, 361-363.

38. Nagel, R.L. and Steinberg, M.H. (2001) Hemoglobins of the embryo and fetus and minor hemoglobins of adults. In Disorders of Hemoglobin: Genetics, Pathophysiology, and Clinical Management. Steinberg, M.H., Forget, B.G., Higgs, D.R., and Nagel, R.L., Eds. Cambridge University Press, Cambridge, pp. 197-230.

39. Papayannopoulou, T.H., Brice, M., and Stamatoyannopoulos, G. (1976) Stimulation of fetal hemoglobin synthesis in bone marrow cultures from adult individuals. Proc. Natl. Acad. Sci. U. S. A. 73, 2033-2037.

40. Papayannopoulou, T., Brice, M., and Stamatoyannopoulos, G. (1977) Hemoglobin F synthesis in vitro: evidence for control at the level of primitive erythroid stem cells. Proc. Natl. Acad. Sci. U. S. A. 74, 29232927.

41. Blau, C.A., Constantoulakis, P., al-Khatti, A., Spadaccino, E., Goldwasser, E., Papayannopoulou, T., and Stamatoyannopoulos, G. (1993) Fetal hemoglobin in acute and chronic states of erythroid expansion. Blood 81, 227-233.

42. Asano, H., Li, X.S., and Stamatoyannopoulos, G. (2000) FKLF-2: a novel Kruppel-like transcriptional factor that activates globin and other erythroid lineage. Blood 95, 3578-3584.

43. Donze, D., Townes, T.M., and Bieker, J.J. (1995) Role of erythroid Kruppel-like factor in human $\gamma$ - to $\beta$ globin gene switching. J. Biol. Chem. 270, 1955-1959.

44. Yang, Y., Duan, Z.J., Skarpidi, E., Li, Q.L., Papayannopoulou, T., and Stamatoyannopoulos, G. (2001) Cloning and characterization of a potential transcriptional activator of human gamma-globin genes. Blood Cells Mol. Dis. 27, 1-15.

45. Torrealba-de Ron, A.T., Papayannopoulou, T., Knapp, M.S., Fu, M.F., Knitter, G., and Stamatoyannopoulos, G. (1984) Perturbations in the erythroid marrow progenitor cell pools may play a role in the augmentation of HbF by 5-azacytidine. Blood 63, 201-210.

46. Tagger, A.Y., Boux, J., and Wright, J.A. (1987) Hydroxy $\left[{ }^{14}\right.$ C $]$ urea uptake by normal and transformed human cells: evidence for a mechanism of passive diffusion. Biochem. Cell Biol. 65, 925-929.

47. Timson, J. (1975) Hydroxyurea. Mutat. Res. 32, 115-132.

48. Stevens, M.R. (1999) Hydroxyurea: an overview. J. Biol. Regul. Homeost. Agents 13, 172-175.

49. Gwilt, P.R. and Tracewell, W.G. (1998) Pharmacokinetics and pharmacodynamics of hydroxyurea. Clin. Pharmacokinet. 34, 347-358. 
50. Colvin, M. and Bono, V.H. (1970) The enzymztic reduction of hydroxyurea to urea by mouse liver. Cancer Res. 30, 1516-1517.

51. Andrae, U. (1984) Evidence for involvement of Cytochrome P-450-dependant monooxygenase in the formation of genotoxic metabolites from $N$-hydroxyurea. Biochem. Biophys. Res. Commun. 118, 409-415.

52. Fishbein, W.N. and Carbone, P.P. (1963) Hydroxyurea: mechanisms of action. Science 142, 1069-1070. Yarbro, J.W. (1992) Mechanism of action of hydroxyurea. Semin. Oncol. 19, 1-10.

Letvin, N.L., Linch, D.C., Beardsley, P., McIntyre, K.W., and Nathan, D.G. (1984) Augmentation of fetal hemoglobin in anemic monkeys by hydroxyurea. N. Engl. J. Med. 310, 869-874.

55. Platt, O.S., Orkin, S.H., Dover, G., Beardsley, G.P., Miller, B., and Nathan, D.G. (1984) Hydroxyurea enhances fetal hemoglobin production in sickle cell anemia. J. Clin. Invest. 74, 652-656.

56. Charache, S., Dover, G.J., Moyer, M.A., and Moore, J.W. (1987) Hydroxyurea-induced augmentation of fetal hemoglobin production in patients with sickle cell anemia. Blood 69, 109-116.

57. Charache, S., Dover, G.J., Moore, R.D., Eckert, S., Ballas, S.K., Koshy, M., Milner, P.F.A., Orringer, E.P., Phillips, G., Jr., Platt, O.S., and Thomas, G.H. (1992) Hydroxyurea: effects on hemoglobin F production in patients with sickle cell anemia. Blood 79, 2555-2565.

58. Dover, G.J., Humphries, R.K., Moore, J.G., Ley, T.J., Young, N.S., Charache, S., and Nienhuis, A.W. (1986) Hydroxyurea induction of hemoglobin F production in sickle cell disease: relationship between cytotoxicity and $\mathrm{F}$ cell production. Blood 67, 735-738.

59. Charache, S., Terrin, M.L., Moore, R.D., Dover, G.J., Barton, F.B., Eckert, S.V., McMahon, R.P., Bonds, D.R., and Multicenter Study of Hydroxyurea in Sickle Cell Anemia (1995) Effect of hydroxyurea on the frequency of painful crises in sickle cell anemia. N. Engl. J. Med. 332, 1317-1322.

60. Steinberg, M.H., Lu, Z.-H., Barton, F.B., Terrin, M.L., Charache, S., Dover, G.J., and Multicenter Study of Hydroxyurea (1997) Fetal hemoglobin in sickle cell anemia: determinants of response to hydroxyurea. Blood 89, 1078-1088.

61. Charache, S., Terrin, M.L., Moore, R.D., Dover, G.J., McMahon, R.P., Barton, F.B., Waclawiw, M., and Eckert, S.V. (1995) Design of the multicenter study of hydroxyurea in sickle cell anemia. Control. Clin. Trials 16, 432-446.

62. Ballas, S.K., Marcolina, M.J., Dover, G.J., and Barton, F.B. (1999) Erythropoietic activity in patients with sickle cell anaemia before and after treatment with hydroxyurea. Br. J. Haematol. 105, 491-496.

63. Hackney, A.C., Hezier, W., Gulledge, T.P., Jones, S., Strayhorn, D., Busby, M., Hoffman, E., and Orringer, E.P. (1997) Effects of hydroxyurea administration on the body weight, body composition and exercise performance of patients with sickle-cell anaemia. Clin. Sci. 92, 481-486.

64. Scott, J.P., Hillery, C.A., Brown, E.R., Misiewicz, V., and Labotka, R.J. (1996) Hydroxyurea therapy in children severely affected with sickle cell disease. J. Pediatr. 128, 820-828.

65. Jayabose, S., Tugal, O., Sandoval, C., Patel, P., Puder, D., Lin, T., and Visintainer, P. (1996) Clinical and hematologic effects of hydroxyurea in children with sickle cell anemia. J. Pediatr. 129, 559-565.

66. Ferster, A., Vermylen, C., Cornu, G., Buyse, M., Corazza, F., Devalck, C., Fondu, P., Toppet, M., and Sariban, E. (1996) Hydroxyurea for treatment of severe sickle cell anemia: a pediatric clinical trial. Blood $\mathbf{8 8}$, 1960-1964.

67. Olivieri, N.F. and Vichinksy, E.P. (1998) Hydroxyurea in children with sickle cell disease: impact on splenic function and compliance with therapy. J. Pediatr. Hematol. Oncol. 20, 26-31.

68. Maier-Redelsperger, M., De Montalembert, M., Flahault, A., Neonato, M.G., Ducrocq, R., Masson, M.P., Girot, R., Elion, J., and French Study Group on Sickle Cell Disease (1998) Fetal hemoglobin and F-cell responses to long-term hydroxyurea treatment in young sickle cell patients. Blood 91, 4472-4479.

69. Ferster, A., Tahriri, P., Vermylen, C., Sturbois, G., Corazza, F., Fondu, P., Devalck, C., Dresse, M.F., Feremans, W., Hunninck, K., Toppet, M., Philippet, P., Van Geet, C., and Sariban, E. (2001) Five years of experience with hydroxyurea in children and young adults with sickle cell disease. Blood 97, 3628-3632.

70. De Montalembert, M., Bégué, P., Bernaudin, F., Thuret, I., Bachir, D., and Micheau, M. (1999) Preliminary report of a toxicity study of hydroxyurea in sickle cell disease. French Study Group on Sickle Cell Disease. Arch. Dis. Child. 81, 437-439.

71. Kinney, T.R., Helms, R.W., O'Branski, E.E., Ohene-Frempong, K., Wang, W., Daeschner, C., Vichinsky, E., Redding-Lallinger, R., Gee, B., Platt, O.S., Ware, R.E., and Pediat, H.G. (1999) Safety of hydroxyurea in children with sickle cell anemia: results of the HUG-KIDS study, a Phase I/II trial. Blood 94, 15501554.

72. Parasuraman, S., Rodman, J.H., Ware, R.E., Liu, A., Wynn, L., and Wang, W.C. (1998) Pharmacokinetics (PK) of hydroxyurea (HU) in children with sickle cell anemia (SCA). Blood 92, $32 \mathrm{~b}$.

73. Ware, R.E., Eggleston, B., Redding-Lallinger, R., Wang, W.C., Smith-Whitley, K., Daeschner, C., Gee, B., Styles, L.A., Helms, R.W., Kinney, T.R., and Ohene-Frempong, K. (2002) Predictors of fetal hemoglobin response in children with sickle cell anemia receiving hydroxyurea therapy. Blood 99, 10-14.

74. Hoppe, C., Van Warmerdam, J., Allen, K., Quirlo, K., and Vichinsky, E. (1999) The safety and efficacy of hydroxyurea in 2 to 5 year old children with sickle cell disease. 23rd Annual Meeting of the National Sickle Cell Disease Program, 99. 
75. Wang, W.C., Wynn, L.W., Rogers, Z.R., Scott, J.P., Lane, P.A., and Ware, R.E. (2001) A two-year pilot trial of hydroxyurea in very young children with sickle-cell anemia. J. Pediatr. 139, 790-796.

76. Horiuchi, K., Golden, J.A., Das, S.K., Scully, M., Lian, L., Ohene-Frempong, K., and Asakura, T. (1998) Adverse effects of hydroxyurea on growth and development of young mice. Blood 92, 160a.

77. Muraca, M.F., Sharma, S., Gilday, D., Brown, E., Nili, N., and Olivieri, N.F. (1999) Prospective study of splenic hypofunction during therapy with hydroxyurea in patients with sickle cell disease. Blood 94, 415a.

78. Claster, S. and Vichinsky, E. (1996) First report of reversal of organ dysfunction in sickle cell anemia by the use of hydroxyurea: splenic regeneration. Blood 88, 1951-1953.

79. Muraca, M.F., Schinkel, H., Brown, E., and Olivieri, N.F. (1998) Splenic function in patients with sickle cell disease treated with hydroxyurea. Blood $\mathbf{9 2}, 32 \mathrm{~b}$.

80. Sutton, M., Weinberg, R.S., Padilla, M., Perrine, S.P., and Atweh, G.F. (1999) Progressive pulmonary hypertension and pulmonary insufficiency in sickle cell patients who respond to hydroxxyurea. Blood 94, 416a.

81. Steinberg, M.H., Nagel, R.L., and Brugnara, C. (1997) Cellular effects of hydroxyurea in Hb SC disease. $B r$. J. Haematol. 98, 838-844.

82. Ware, R.E., Sommerich, M., Zimmerman, S.A., O'Branski, E.E., and Schultz, W.H. (1999) Hydroxyurea therapy for pediatric patients with Hemoglobin SC disease: laboratory and clinical effects. 23rd Annual Meeting of the National Sickle Cell Disease Program, 170.

83. Iyer, R., Baliga, R., Nagel, R.L., Brugnara, C., Kirchner, K.A., Hogan, S., and Steinberg, M.H. (2000) Maximum urine concentrating ability in children with $\mathrm{Hb} \mathrm{SC}$ disease: effects of hydroxyurea. Am. $J$. Hematol. 64, 47-52.

84. Hilliard, L., Maddox, M., and Howard, T. (2001) Hydroxyurea in pediatric patients with hemoglobin SC disease. 25th Annual Meeting of the National Sickle Cell Disease Program, 98a.

85. Voskaridou, E., Kalotychou, V., and Loukopoulos, D. (1995) Clinical and laboratory effects of long-term administration of hydroxyurea to patients with sickle-cell/3-thalassaemia. Br. J. Haematol. 89, 479-484.

86. Loukopoulos, D. (1996) Current status of thalassemia and the sickle cell syndromes in Greece. Semin. Hematol. 33, 76-86.

87. Rigano, P., Rodgers, G.P., Renda, D., Renda, M.C., Aquino, A., and Maggio, A. (2001) Clinical and hematological responses to hydroxyurea in Sicilian patients with $\mathrm{Hb}$ S/beta-thalassemia. Hemoglobin 25, 9-17.

88. Ware, R.E., Steinberg, M.H., and Kinney, T.R. (1995) Hydroxyurea: an alternative to transfusion therapy for stroke in sickle cell anemia. Am. J. Hematol. 50, 140-143.

89. Adams, R.J., Carl, E.J., McKie, V.C., Odo, N.A., Kutlar, A., Phillips, M., and Brambilla, D. (1999) A pilot trial of hydroxyurea to prevent strokes in children with sickle cell anemia. 23rd Annual Meeting of the National Sickle Cell Disease Program, 53.

90. Ware, R.E., Zimmerman, S.A., O'Branski, E.E., and Schultz, W.H. (1999) Hydroxyurea as an alternative to blood transfusions for the prevention of recurrent stroke in children with sickle cell disease. 23rd Annual Meeting of the National Sickle Cell Disease Program, 172.

91. Schmugge, M., Frischknecht, H., Yonekawa, Y., Baumgartner, R.W., Boltshauser, E., and Humbert, J. (2001) Stroke in hemoglobin (SD) sickle cell disease with moyamoya: successful hydroxyurea treatment after cerebrovascular bypass surgery. Blood 97, 2165-2167.

92. Vichinsky, E.P. and Lubin, B.H. (1994) A cautionary note regarding hydroxyurea in sickle cell disease. Blood 83, 1124-1128.

93. Anson, J.A., Koshy, M., Ferguson, L., and Crowell, R.M. (1991) Subarachnoid hemorrhage in sickle-cell disease. J. Neurosurg. 75, 552-558.

94. Ohene-Frempong, K., Weiner, S.J., Sleeper, L.A., Miller, S.T., Embury, S., Moohr, J.W., Wethers, D.L., Pegelow, C.H., Gill, F.M., and Cooperative Study Sickle Cell Disease (1998) Cerebrovascular accidents in sickle cell disease: Rates and risk factors. Blood 91, 288-294.

95. Steinberg, M.H., Barton, F., Castro, O., Koshy, M., Pegelow, C., Ballas, S.K., Kutlar, A., Orringer, E.P., Bellevue, R., Olivieri, N., Eckman, J., Bridges, K., Varma, M., Ramirez, G.M., Adler, B., Smith, W., Claster, S., Shurin, S.B., Vichinksy, E.P., Carlos, T., Telfer, M., Ataga, K.I., DeCastro, L., Bigelow, C., Saunthararajah, Y., Waclawiw, M., Bonds, D., and Terrin, M. (2002) Effect of hydroxyurea on mortality and morbidity in sickle cell anemia: risks and benefits up to 9 years of treatment, submitted.

96. Nadvi, S.Z., Panchoosingh, H., Thomas, R., and Sarnaik, S. (1998) Use of hydroxyurea in patients with sickle cell anemia on chronic transfusion. Blood $\mathbf{9 2}, 32 \mathrm{~b}$.

97. Hannah, A., McKie, V., McKie, K.M., Holley, L., Kutlar, F., Adams, R.J., Nichols, F.T., Woods, K.F., and Kutlar, A. (1999) Combination of hydroxyurea and a modified transfusion regimen in secondary stroke prevention on sickle cell disease. 23rd Annual Meeting of the National Sickle Cell Disease Program, 96.

98. Rodgers, G.P., Dover, G.J., Noguchi, C.T., Schechter, A.N., and Nienhuis, A.W. (1990) Hematologic responses of patients with sickle cell disease to treatment with hydroxyurea. N. Engl. J. Med. 322, 10371045 .

99. El-Hazmi, M.A.F., Al-Momen, A., Kandaswamy, S., Huraib, S., Harakati, M., Al-Mohareb, F., and Warsy, A.S. (1995) On the use of hydroxyurea erythropoietin combination therapy for sickle cell disease. Acta Haematol. 94, 128-134. 
100. Rodriguez, G.I., Kuhn, J.G., Weiss, G.R., Hilsenbeck, S.G., Eckardt, J.R., Thurman, A., Rinaldi, D.A., Hodges, S., Von Hoff, D.D., and Rowinsky, E.K. (1998) A bioavailability and pharmacokinetic study of oral and intravenous hydroxyurea. Blood 91, 1533-1541.

101. McDonagh, K.T., Dover, G.J., Donahue, R.E., Nathan, D.G., Agricola, B., Byrne, E., and Nienhuis, A.W. (1992) Hydroxyurea-induced $\mathrm{HbF}$ production in anemic primates: augmentation by erythropoietin, hematopoietic growth factors, and sodium butyrate. Exp. Hematol. 20, 1156-1164.

102. al-Khatti, A., Papayannopoulou, T., Knitter, G., Fritsch, E.F., and Stamatoyannopoulos, G. (1988) Cooperative enhancement of F-cell formation in baboons treated with erythropoietin and hydroxyurea. Blood 72, 817-819.

103. al-Khatti, A., Umemura, T., Clow, J., Abels, R.I., Vance, J., Papayannopoulou, T., and Stamatoyannopoulos, G. (1988) Erythropoietin stimulates F-reticulocyte formation in sickle cell anemia. Trans. Assoc. Am. Physicians 101, 54-61.

104. Rodgers, G.P., Dover, G.J., Uyesaka, N., Noguchi, C.T., Schechter, A.N., and Nienhuis, A.W. (1993) Augmentation by erythropoietin of the fetal-hemoglobin response to hydroxyurea in sickle cell disease. $N$. Engl. J. Med. 328, 73-80.

105. El-Hazmi, M.A.F., Al-Momen, A., Warsy, A.S., Kandaswamy, S., Huraib, S., Harakati, M., and Al-Mohareb, F. (1995) The pharmacological manipulation of fetal haemoglobin: trials using hydroxyurea and recombinant human erythropoietin. Acta Haematol. 93, 57-61.

106. Sutton, M., Nassif, I., Stamatoyannopoulos, G., Perrine, S.P., and Atweh, G.F. (1998) Absence of crossresistance to the $\mathrm{Hb} F$ stimulating activities of butyrate and hydroxyurea. Blood $\mathbf{9 2}, 694 \mathrm{a}$.

107. Miller, B.A., Perrine, S.P., Bernstein, A., Lyman, S.D., Williams, D.E., Bell, L.L., and Olivieri, N.F. (1992) Influence of steel factor on hemoglobin synthesis in sickle cell disease. Blood 79, 1861-1868.

108. Lavelle, D., Molokie, R., Ducksworth, J., and DeSimone, J. (2001) Effects of hydroxurea, stem cell factor, and erythropoietin in combination on fetal hemoglobin in the baboon. Exp. Hematol. 29, 156-162.

109. Gabbianelli, M., Testa, U., Massa, A., Pelosi, E., Sposi, N.M., Riccioni, R., Luchetti, L., and Peschle, C. (2000) Hemoglobin switching in unicellular erythroid culture of sibling erythroid burst-forming units: kit ligand induces a dose-dependent fetal hemoglobin reactivation potentiated by sodium butyrate. Blood $\mathbf{9 5}$, 3555-3561.

110. Bohmer, R.M., Campbell, T.A., and Bianchi, D.W. (2000) Selectively increased growth of fetal hemoglobinexpressing adult erythroid progenitors after brief treatment of early progenitors with transforming growth factor beta. Blood 95, 2967-2974.

111. Hanft, V.N., Fruchtman, S.R., Pickens, C.V., Rosse, W.F., Howard, T.A., and Ware, R.E. (2000) Acquired DNA mutations associated with in vivo hydroxyurea exposure. Blood 95, 3589-3593.

112. Triadou, P., Maier-Redelsperger, M., Krishnamoorthy, R., Deschamps, A., Casadevall, N., Dunda, O., Ducrocq, R., Elion, J., Girot, R., and Labie, D. (1994) Fetal hemoglobin variations following hydroxyurea tratement in patients with cyanotic congenital heart disease. Nouv. Rev. Fr. Hematol. 36, 367-372.

113. Weinfeld, A., Swolin, B., and Westin, J. (1994) Acute leukaemia after hydroxyurea therapy in polycythemia vera and allied disorders: prospective study of efficacy and leukaemogenicity with therapeutic implications. Eur. J. Haematol. 52, 134-139.

114. Nand, S., Stock, W., Godwin, J., and Fisher, S.G. (1996) Leukemogenic risk of hydroxyurea therapy in polycythemia vera, essential thrombocythemia, and myeloid metaplasia with myelofibrosis. Am. J. Hematol. 52, 42-46.

115. Najean, Y. and Rain, J.D. (1997) Treatment of polycythemia vera: the use of hydroxyurea and pipobroman in 292 patients under the age of 65 years. Blood 90, 3370-3377.

116. Najean, Y. and Rain, J.-D. (1997) Treatment of polycythemia vera: use of ${ }^{32} \mathrm{P}$ alone or in combination with maintenance therapy using hydroxyurea in 461 patients greater than 65 years of age. Blood 89, 2319-2327.

117. Fenaux, P., Preudhomme, C., Laï, J.L., and Sterkers, Y. (1998) Is hydroxyurea leukemogenic in essential thrombocythemia? Response. Blood 92, 1460-1461.

118. Sterkers, Y., Preudhomme, C., Laï, J.L., Demory, J.L., Caulier, M.T., Wattel, E., Bordessoule, D., Bauters, F., and Fenaux, P. (1998) Acute myeloid leukemia and myelodysplastic syndromes following essential thrombocythemia treated with hydroxyurea: high proportion of cases with $17 \mathrm{p}$ deletion. Blood 91, 616622.

119. Liozon, E., Brigaudeau, C., Trimoreau, F., Desangles, F., Fermeaux, V., Praloran, V., and Bordessoule, D. (1997) Is treatment with hydroxyurea leukemogenic in patients with essential thrombocythemia? - An analysis of three new cases of leukaemic transformation and review of the literature. Hematol. Cell Ther. 39, 11-18.

120. Barbul, T., Finazzi, G., Ruggeri, M., and Rideghiero, F. (1998) Secondary leukemia following hydroxyurea in patients with essential thromocythemia: long-term results of a randomized clinical trial. Blood 92, 489a.

121. Wilson, S. (2000) Acute leukemia in a patient with sickle-cell anemia treated with hydroxyurea. Ann. Intern. Med. 133, 925-926.

122. Rauch, A., Borromeo, M., and Ghafoor, A. (1999) Leukemogenesis of hydroxyurea in the treatment of sickle cell anemia. Blood 94, 415a. 
123. Dawkins, F.W., Kim, K.S., Squires, R.S., Chisholm, R., Kark, J.A., Perlin, E., and Castro, O. (1997) Cancer incidence rate and mortality rate in sickle cell disease patients at Howard University Hospital: 1986-1995. Am. J. Hematol. 55, 188-192.

124. Stricker, R.B., Linker, C.A., Crowley, T.J., and Embury, S.H. (1986) Hematologic malignancy in sickle cell disease: report of four cases and review of the literature. Am. J. Hematol. 21, 223-230.

125. Steinberg, M.H., Castro, O., Ballas, S.K., Barton, F., and Terrin, M. (1998) The multicenter study of hydroxyurea in sickle cell anemia (MSH): mortality at 5-6 years. Blood 92, 496a.

126. Diav-Citrin, O., Hunnisett, L., Sher, G.D., and Koren, G. (1999) Hydroxyurea use during pregnancy: a case report in sickle cell disease and review of the literature. Am. J. Hematol. 60, 148-150.

127. Adams-Graves, P., Heltsley, C., and Deitcher, S. (1996) Hydroxyurea in sickle cell disease. N. Engl. J. Med. 334(333), 334.

128. Best, P.J., Daoud, M.S., Pittelkow, M.R., and Petitt, R.M. (1998) Hydroxyurea-induced leg ulceration in 14 patients. Ann. Intern. Med. 128, 29-32.

129. Norhaya, M.R., Cheong, S.K., Ainoon, O., and Hamidah, N.H. (1997) Painful oral ulcers with hydroxyurea therapy. Singapore Med. J. 38, 283-284.

130. Ravandi-Kashani, F., Cortes, J., Cohen, P., Talpaz, M., O'Brien, S., Thomans, D., Markowitz, A., and Kantarjian, H. (1998) Cutaneous ulcers associated with hydroxyurea (HU) therapy in myeloproliferative disorders. Blood 92, $248 \mathrm{~b}$.

131. Kido, M., Tago, O., Fujiwara, H., Ito, M., and Niwano, H. (1998) Leg ulcer associated with hydroxyurea treatment in a patient with chronic myelogenous leukaemia: successful treatment with prostaglandin $\mathrm{E}_{1}$ and pentoxifylline. Br. J. Dermatol. 139, 1124-1126.

132. Chaine, B., Neonato, M.G., Girot, R., and Aractingi, S. (2001) Cutaneous adverse reactions to hydroxyurea in patients with sickle cell disease. Arch. Dermatol. 137, 467-470.

133. Platt, O.S., Brambilla, D.J., Rosse, W.F., Milner, P.F., Castro, O., Steinberg, M.H., and Klug, P.P. (1994) Mortality in sickle cell disease: life expectancy and risk factors for early death. N. Engl. J. Med. 330, 16391644 .

134. Charache, S., Barton, F.B., Moore, R.D., Terrin, M.L., Steinberg, M.H., Dover, G.J., Ballas, S.K., McMahon, R.P., Castro, O., and Orringer, E.P. (1996) Hydroxyurea and sickle cell anemia - clinical utility of a myelosuppressive "switching" agent. Medicine (Baltimore) 75, 300-326.

135. Fadlon, E., Vordermeier, S., Pearson, T.C., Mire-Sluis, A.R., Dumonde, D.C., Phillips, J., Fishlock, K., and Brown, K.A. (1998) Blood polymorphonuclear leukocytes from the majority of sickle cell patients in the crisis phase of the disease show enhanced adhesion to vascular endothelium and increased expression of CD64. Blood 91, 266-274.

136. Hebbel, R.P., Boogaerts, M.A., Eaton, J.W., and Steinberg, M.H. (1980) Erythrocyte adherence to endothelium in sickle-cell anemia. A possible determinant of disease severity. N. Engl. J. Med. 302, 992-995.

137. Sugihara, K., Sugihara, T., Mohandas, N., and Hebbel, R.P. (1992) Thrombospondin mediates adherence of $\mathrm{CD}^{+} 6^{+}$sickle reticulocytes to endothelial cells. Blood 80, 2634-2642.

138. Wick, T.M., Moake, J.L., Udden, M.M., and McIntire, L.V. (1993) Unusually large von Willebrand factor multimers preferentially promote young sickle and nonsickle erythrocyte adhesion to endothelial cells. Am. J. Hematol. 42, 284-292.

139. Swerlick, R.A., Eckman, J.R., Kumar, A., Jeitler, M., and Wick, T.M. (1993) $\alpha_{4} \beta_{1}$-Integrin expression on sickle reticulocytes: vascular cell adhesion molecule-1-dependent binding to endothelium. Blood 82, 18911899.

140. Gee, B.E. and Platt, O.S. (1995) Sickle reticulocytes adhere to VCAM-1. Blood 85, 268-274.

141. Brittain, H.A., Eckman, J.R., Swerlick, R.A., Howard, R.J., and Wick, T.M. (1993) Thrombospondin from activated platelets promotes sickle erythrocyte adherence to human microvascular endothelium under physiologic flow: a potential role for platelet activation in sickle cell vaso-occlusion. Blood 81, 2137-2143.

142. Joneckis, C.C., Ackley, R.L., Orringer, E.P., Wayner, E.A., and Parise, L.V. (1993) Integrin $\alpha_{4} \beta_{1}$ and glycoprotein IV (CD36) are expressed on circulating reticulocytes in sickle cell anemia. Blood 82, 35483555 .

143. Bridges, K.R., Barabino, G.D., Brugnara, C., Cho, M.R., Christoph, G.W., Dover, G., Ewenstein, B.M., Golan, D.E., Guttmann, C.R.G., Hofrichter, J., Mulkern, R.V., Zhang, B., and Eaton, W.A. (1996) A multiparameter analysis of sickle erythrocytes in patients undergoing hydroxyurea therapy. Blood 88, 4701-4710.

144. Adragna, N.C., Fonseca, P., and Lauf, P.K. (1994) Hydroxyurea affects cell morphology cation transport and red blood cell adhesion in cultured vascular endothelial cells. Blood 83, 553-560.

145. Styles, L.A., Lubin, B., Vichinsky, E., Lawrence, S., Hua, M., Test, S., and Kuypers, F. (1997) Decrease of very late activation antigen-4 and CD36 on reticulocytes in sickle cell patients treated with hydroxyurea. Blood 89, 2554-2559.

146. Ballas, S.K., Dover, G.J., and Charache, S. (1991) Effect of hydroxyurea on the rheological properties of sickle erythrocytes in vivo. Am. J. Hematol. 32, 104-111.

147. Saleh, A.W., Hillen, H.F.P., and Duits, A.J. (1999) Levels of endothelial, neutrophil and platelet-specific factors in sickle cell anemia patients during hydroxyurea therapy. Acta Haematol. 102, 31-37. 
148. Hillery, C.A., Du, M.C., Wang, W.C., and Scott, J.P. (2000) Hydroxyurea therapy decreases the in vitro adhesion of sickle erythrocytes to thrombospondin and laminin. Br. J. Haematol. 109, 322-327.

149. Sato, K., Akaike, T., Sawa, T., Miyamoto, Y., Suga, M., Ando, M., and Maeda, H. (1997) Nitric oxide generation from hydroxyurea via copper-catalyzed peroxidation and implications for pharmacological actions of hydroxyurea. Jpn. J. Cancer Res. 88, 1199-1204.

150. Jiang, J., Jordan, S.J., Barr, D.P., Gunther, M.R., Maeda, H., and Mason, R.P. (1997) In vivo production of nitric oxide in rats after administration of hydroxyurea. Mol. Pharmacol. 52, 1081-1086.

151. Xu, Y.P., Mull, C.D., Bonifant, C.L., Yasaki, G., Palmer, E.C., Shields, H., Ballas, S.K., Kim-Shapiro, D.B., and King, S.B. (1998) Nitrosylation of sickle cell hemoglobin by hydroxyurea. J. Org. Chem., 63, 64526453 .

152. Glover, R.E., Ivy, E.D., Orringer, E.P., Maeda, H., and Mason, R.P. (1999) Detection of nitrosyl hemoglobin in venous blood in the treatment of sickle cell anemia with hydroxyurea. Mol. Pharmacol. 55, 1006-1010.

153. Head, C.A., Brugnara, C., Martinez-Ruiz, R., Kacmarek, R.M., Bridges, K.R., Kuter, D., Bloch, K.D., and Zapol, W.M. (1997) Low concentrations of nitric oxide increase oxygen affinity of sickle erythrocytes in vitro and in vivo. J. Clin. Invest. 100, 1193-1198.

154. Gladwin, M.T., Schechter, A.N., Shelhamer, J.H., Pannell, L.K., Conway, D.A., Hrinczenko, B.W., Nichols, J.S., Pease-Fye, M.E., Noguchi, C.T., Rodgers, G.P., and Ognibene, F.P. (1999) Inhaled nitric oxide augments nitric oxide transport on sickle cell hemoglobin without affecting oxygen affinity. J. Clin. Invest. 104, 937-945.

155. Stamler, J.S., Jia, L., Eu, J.P., McMahon, T.J., Demchenko, I.T., Bonaventura, J., Gernert, K., and Piantadosi, C.A. (1997) Blood flow regulation by S-nitrosohemoglobin in the physiological oxygen gradient. Science 276, 2034-2037.

156. Kim-Shapiro, D.B., King, S.B., Bonifant, C.L., and Ballas, S.K. (1997) Hydroxyurea reacts with sickle cell hemoglobin to form methemoglobin and other minor species. Blood 90, 28b.

157. Beutler, E. and Mikus, B.J. (1961) Effect of methemoglobin formation in sickle cell disease. J. Clin. Invest. 40, 1856-1871.

158. Huang, Z., Louderback, J.G., King, S.B., Ballas, S.K., and Kim-Shapiro, D.B. (2001) In vitro exposure to hydroxyurea reduces sickle red blood cell deformability. Am. J. Hematol. 67, 151-156.

159. Papassotiriou, I, Stamoulakatou, A., Voskaridou, E., Stamou, E., and Loukopoulos, D. (1998) Hydroxyurea induced erythropoietin secretion in sickle cell syndromes may contribute in their HbF increase. Blood $\mathbf{9 2}$, 160a.

160. Valafar, H., Valafar, F., Darvill, A., Albersheim, P., Kutlar, A., Woods, K.F., and Hardin, J. (2000) Predicting the effectiveness of hydroxyurea in individual sickle cell anemia patients. Artif. Intell. Med. 18, 133-148.

161. Hayes, R.J., Beckford, M., Grandison, Y., Mason, K., Serjeant, B.E., and Serjeant, G.R. (1985) The haematology of steady state homozygous sickle cell disease: frequency distributions variation with age and sex, longitudinal observations. Br. J. Haematol. 59, 369-382.

162. West, M.S., Wethers, D., Smith, J., Steinberg, M.H., and Coop Study of Sickle Cell Disease (1992) Laboratory profile of sickle cell disease: a cross-sectional analysis. J. Clin. Epidemiol. 45, 893-909.

163. Dimovski, A.J., Öner, C., Agarwal, S., Gu, Y.-C., Gu, L.-H., Kutlar, F., Lanclos, K.D., and Huisman, T.H.J. (1991) Certain mutations observed in the 5 ' sequences of the ${ }^{\mathrm{G}}$ gamma- and Aamma-globin genes of $\beta^{\mathrm{S}}$ chromosomes are specific for chromosomes with major haplotypes. Acta Haematol. (Basel) 85, 79-87.

164. Lanclos, K.D., Öner, C., Dimovski, A.J., Gu, Y.-C., and Huisman, T.H.J. (1991) Sequence variations in the 5' flanking and IVS-II regions of the ${ }^{\mathrm{G}} \gamma$ - and ${ }^{\mathrm{A}} \gamma$-globin genes of $\beta^{\mathrm{S}}$ chromosomes with five different haplotypes . Blood 77, 2488-2496.

165. Lu, Z.H. and Steinberg, M.H. (1996) Fetal hemoglobin in sickle cell anemia: relation to regulatory sequences cis to the $\beta$-globin gene. Blood 87, 1604-1611.

166. Plonczynski, M., Figueiredo, M.S., and Steinberg, M.H. (1997) Fetal hemoglobin in sickle cell anemia: examination of phylogenetically conserved sequences within the locus control region but outside the cores of hypersensitive sites 2 and 3. Blood Cells Mol. Dis. 23, 188-200.

167. Pissard, S. and Beuzard, Y. (1994) A potential regulatory region for the expression of fetal hemoglobin in sickle cell disease. Blood 84, 331-338.

168. Ofori-Acquah, S.F., Lalloz, M.R.A., and Layton, D.M. (1999) Localisation of cis regulatory elements at the $\beta$-globin locus: analysis of hybrid haplotype chromosomes. Biochem. Biophys. Res. Commun. 254, 181-187.

169. Caterina, J.J., Ryan, T.M., Pawlik, K.M., Palmiter, R.D., Brinster, R.L., Behringer, R.R., and Townes, T.M. (1991) Human $\beta$-globin locus control region: analysis of the 5' DNase I hypersensitive site HS 2 in transgenic mice. Proc. Natl. Acad. Sci. U. S. A. 88, 1626-1630.

170. Jackson, J.D., Petrykowska, H., Philipsen, S., Miller, W., and Hardison, R. (1996) Role of DNA sequences outside the cores of DNase hypersensitive sites (HSs) in functions of the $\beta$-globin locus control region domain opening and synergism between HS2 and HS3. J. Biol. Chem. 271, 11871-11878.

171. Jackson, J.D., Miller, W., and Hardison, R.C. (1996) Sequences within and flanking hypersensitive sites 3 and 2 of the $\beta$-globin locus control region required for synergistic versus additive interaction with the $\varepsilon$ globin gene promoter. Nucleic Acids Res. 24, 4327-4335. 
172. Hardison, R.C., Oeltjen, J., and Miller, W. (1997) Long human-mouse sequence alignments reveal novel regulatory elements: a reason to sequence the mouse genome. Genome Res. 7, 959-966.

173. Hardison, R. and Miller, W. (1993) Use of long sequence alignments to study the evolution and regulation of mammalian globin gene clusters. Mol. Biol. Evol. 10, 73-102.

174. Hardison, R., Elnitski, L., Elsherbini, A., Goldstrohm, A., Jackson, J., Peck, J., Riemer, C., Schwartz, S., Stojanovic, N., and Miller, W. (1995) The globin gene server: an aid to studying the regulation of mammalian globin gene clusters. In Molecular Biology of Hemoglobin Switching. Stamatoyannopoulos, G., Ed. Intercept, Andover, U.K. pp. 405-26.

175. Hardison, R., Riemer, C., Chui, D.H., Huisman, T.H., and Miller, W. (1998) Electronic access to sequence alignments, experimental results, and human mutations as an aid to studying globin gene regulation. Genomics, 47, 429-437.

176. Hardison, R., Slightom, J.L., Gumucio, D.L., Goodman, M., Stojanovic, N., and Miller, W. (1997) Locus control regions of mammalian $\beta$-globin gene clusters: combining phylogenetic analyses and experimental results to gain functional insights. Gene 205, 73-94.

177. Amin, B.R., Bauersachs, R.M., Meiselman, H.J., Mohandas, N., Hebbel, R.P., Bowen, P.E., Schlegel, R.A., Williamson, P., and Westerman, M.P. (1991) Monozygotic twins with sickle cell anemia and discordant clinical courses: clinical and laboratory studies. Hemoglobin 15, 247-256.

178. Joishy, S.K., Griner, P.F., and Rowley, P.T. (1976) Sickle beta-thalassemia: identical twins differing in severity implicate nongenetic factors influencing course. Am. J. Hematol. 1, 23-33.

179. Miyoshi, K., Kaneto, Y., Kawai, H., Ohchi, H., Niki, S., Hasegawa, K., Shirakami, A., and Yamano, T. (1988) X-linked dominant control of F-cells in normal adult life: characterization of the Swiss type as hereditary persistence of fetal hemoglobin regulated dominantly by gene(s) on X chromosome. Blood $\mathbf{7 2}$, 1854-1860.

180. Dover, G.J., Smith, K.D., Chang, Y.C., Purvis, S., Mays, A., Meyers, D.A., Sheils, C., and Serjeant, G. (1992) Fetal hemoglobin levels in sickle cell disease and normal individuals are partially controlled by an Xlinked gene located at Xp22.2. Blood 80, 816-824.

181. Thein, S.L., Sampietro, M., Rohde, K., Rochette, J., Weatherall, D.J., Lathrop, G.M., and Demenais, F. (1994) Detection of a major gene for heterocellular hereditary persistence of fetal hemoglobin after accounting for genetic modifiers. Am. J. Hum. Genet. 54, 214-228.

182. Game, L., Close, J., Stephens, P., Mitchell, J., Best, S., Rochette, J., Louis-dit-Sully, C., Riley, J., See, C.G., Sanseau, P., Kearney, L., Bethel, G., Humphray, S., Dunham, I., Mungall, A., and Thein, S.L. (2000) An integrated map of human 6q22.3-q24 including a 3-Mb high-resolution BAC/PAC contig encompassing a QTL for fetal hemoglobin. Genomics 64, 264-276.

183. Garner, C., Tatu, T., Reittie, J.E., Littlewood, T., Darley, J., Cervino, S., Farrall, M., Kelly, P., Spector, T.D., and Thein, S.L. (2000) Genetic influences on F cells and other hematologic variables: a twin heritability study. Blood 95, 342-346.

184. Adekile, A. (1999) Response to hydroxyurea in sickle cell patients with the Saudi Arabia/India haplotype. Blood 94, 416a.

185. Yang, Y.M., Pace, B., Kitchens, D., Ballas, S.K., Shah, A., and Baliga, B.S. (1997) BFU-E colony growth in response to hydroxyurea: correlation between in vitro and in vivo fetal hemoglobin induction. Am. J. Hematol. 56, 252-258.

186. Brugnara, C., De Franceschi, L., and Beuzard, Y. (2001) Erythrocyte-active agents and treatment of sickle cell disease. Semin. Hematol. 38, 324-332.

187. Solovey, A.A., Solovey, A.N., Harkness, J., and Hebbel, R.P. (2001) Modulation of endothelial cell activation in sickle cell disease: a pilot study. Blood 97, 1937-1941.

This article should be referenced as follows:

Steinberg, M.H. (2002) Hydroxyurea treatment for sickle cell disease. TheScientificWorldJOURNAL 2, 1706-1728.

\section{Handling Editor:}

Edward Benz, Principal Editor for Hematology — a domain of TheScientificWorldJOURNAL. 


\section{BIOSKETCH}

Martin Steinberg is Director, Center of Excellence in Sickle Cell Disease, Boston Medical Center and Professor of Medicine and Pediatrics, Boston University. Dr. Steinberg is interested in inherited disorders of hemoglobin and how they may be modified by genetic polymorphisms in other genes. He has won numerous awards and honors, including Alpha Omega Alpha, American Society for Clinical Investigation, Association of American Physicians, Central Society for Clinical Research, Southern Society for Clinical Investigation (President, 1993-1994; Founder's Medalist, 2000); Best Doctors in America, $4^{\text {th }}$ ed.; and Fellow, American Association for the Advancement of Science. 

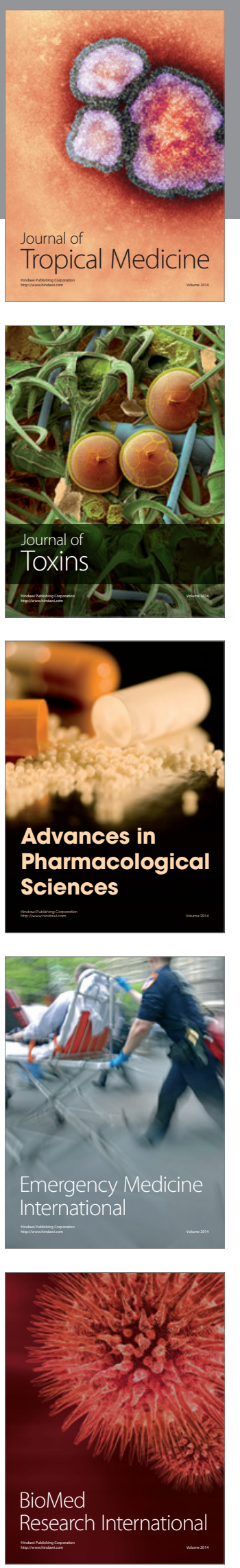
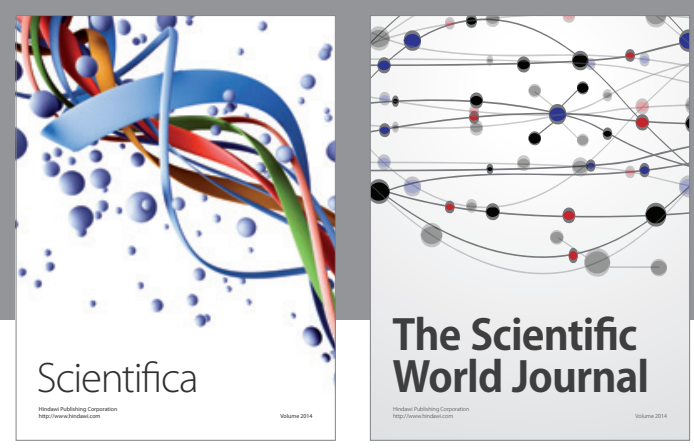

The Scientific World Journal
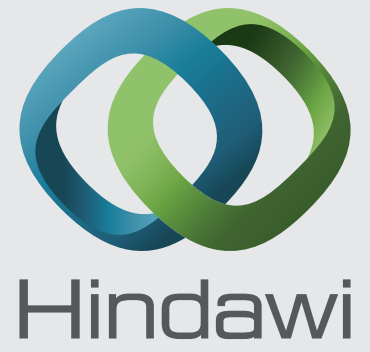

Submit your manuscripts at

http://www.hindawi.com
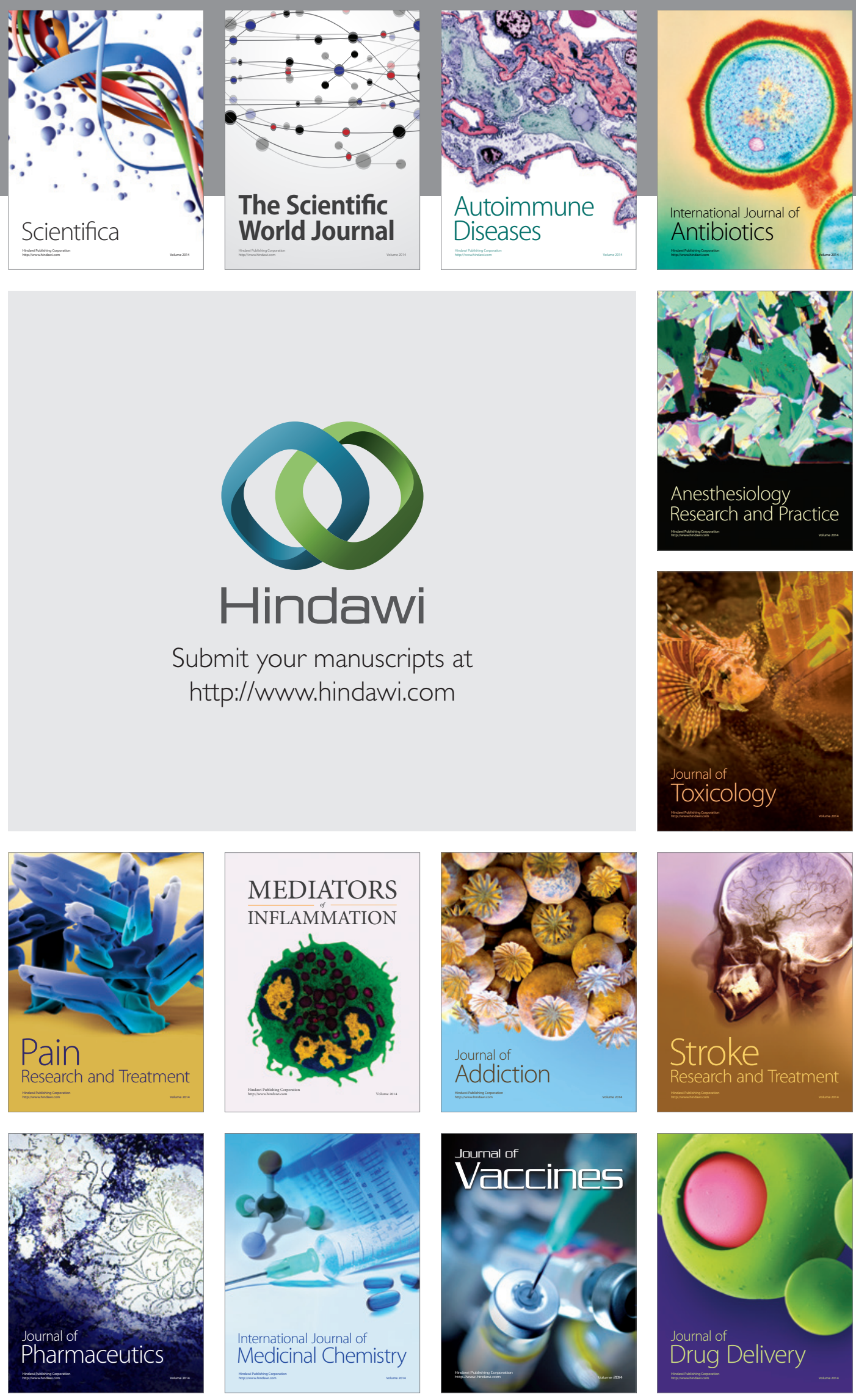